\title{
Source apportionment and the role of meteorological conditions in the assessment of air pollution exposure due to urban emissions
}

\section{Title Page}

\section{Gepartment of Atmospheric Enviro}

${ }^{2}$ Helmholtz Zentrum München, German Research Centre for Environmental Health (HMGU), Joint Mass Spectrometry Centre, Cooperation group "Comprehensive Molecular Analytics", Neuherberg, Germany

${ }^{3}$ Helmholtz Zentrum München, German Research Center for Environmental Health (HMGU), Institutes of Epidemiology I and II (EPI), Neuherberg, Germany

${ }^{4}$ Paul Scherrer Institute (PSI), Gasphase and Aerosol Chemistry Group, Villigen, Switzerland

${ }^{5}$ University of Rostock, Institute of Chemistry, Chair of Analytical Chemistry, Joint Mass

Spectrometry Center, Rostock, Germany

\section{Close}

Full Screen / Esc 
${ }^{6}$ HICE - Helmholtz Virtual Institute of Complex Molecular Systems in Environmental Health Aerosols and Health, Germany

"now at: Bavarian Environment Agency, Augsburg, Germany

Received: 3 December 2013 - Accepted: 9 January 2014 - Published: 24 January 2014

Correspondence to: K. Schäfer (klaus.schaefer@kit.edu)

Published by Copernicus Publications on behalf of the European Geosciences Union.
ACPD

14, 2235-2275, 2014

\section{Meterological}

conditions for air

pollution

K. Schäfer et al.

Title Page

Abstract

Introduction

Conclusions

References

Tables

Figures

14

- I

4

Back

$>$

Close

Full Screen / Esc

Printer-friendly Version

Interactive Discussion 


\section{Abstract}

As particulate matter (PM) impacts human health, knowledge about its composition, exposure and source apportionment is required. A study of the urban atmosphere in the case of Augsburg, Germany, during winter (31 January-12 March 2010) is thus 5 presented here. Investigations were performed on the basis of aerosol mass spectrometry and further air pollutants and meteorological measurements, including mixing layer height. Organic matter was separated by source apportionment of $\mathrm{PM}_{1}$ with positive matrix factorization (PMF) in three factors: OOA - oxygenated organic aerosol (secondary organic factor), HOA - hydrocarbon-like organic aerosol (traffic factor or primary organic factor) and WCOA - wood combustion organic aerosol (wood combustion factor), which extend the information from black carbon (BC) measurements. PMF was also applied to the particle size distribution (PSD) data of $\mathrm{PM}_{2.5}$ to determine different source profiles and we assigned them to the particle sources: nucleation aerosol, fresh traffic aerosol, aged traffic aerosol, stationary combustion aerosol and secondary 15 aerosol. Ten different temporal phases were identified on the basis of weather characteristics and aerosol composition and used for correlations of all air pollutants and meteorological parameters.

While source apportionment from both organic PM composition and PSD agree and show that the main emission sources of PM exposure are road traffic as well as stationary and wood combustion, secondary aerosol factor concentrations are very often the highest ones. The hierarchical clustering analysis with the Ward method of crosscorrelations of each air pollutant and PM component and of the correlations of each pollutant with all meteorological parameters provided two clusters: "secondary pollutants of $\mathrm{PM}_{1}$ and fine particles" and "primary pollutants (including $\mathrm{CO}$ and benzene) and accumulation mode particles". The dominant meteorological influences on pollutant concentrations are wind speed and mixing layer height which are coupled with a certain wind direction. The compounds of the cluster "secondary pollutants and fine particles" show a negative correlation with absolute humidity, i.e., low concentrations
ACPD

$14,2235-2275,2014$

Meterological

conditions for air

pollution

K. Schäfer et al.

Title Page

Abstract 
during high absolute humidity and vice versa. The $\mathrm{PM}_{10}$ limit value exceedances originated not only from the emissions but also in combination with specific meteorological conditions. NC3-10 (number concentration of nucleation mode particles) and NC10-30 (Aitken mode particles), i.e., ultrafine particles and the fresh traffic aerosol, are only 5 weakly dependent on meteorological parameters and thus are driven by emissions. The results of this case study provide information about chemical composition and causes of PM exposure during winter time in urban air pollution.

\section{Introduction}

Particulate matter (PM) and especially ultrafine particles (UFP, diameter $<100 \mathrm{~nm}$ ) are 10 of a high health risk (Rückerl et al., 2011) as particles of smallest diameter penetrate deepest into the lungs, contribute to reduced lung function (Wu et al., 2013) and are then transported to the organs via the bloodstream. It is important from the point of view of health protection to know not only the chemical composition and emission sources, but also the meteorological influences upon the particle number concentration (PNC), 15 particle mass concentration (PMC), different particle size fractions as well as the particle composition.

Urban regions are frequently influenced by enhanced air pollution and limit value exceedances of $\mathrm{PM}_{10}$ (particles with aerodynamic diameters smaller than $10 \mu \mathrm{m}, 24 \mathrm{~h}$ average $\mathrm{PM}_{10}$ of $50 \mathrm{\mu g} \mathrm{m}^{-3}$ should not to be exceeded more than 35 times in any calendar 20 year) and $\mathrm{NO}_{2}$ (hourly limit value of $200 \mu \mathrm{gm}^{-3}$ should not to be exceeded more than 18 times in any calendar year) according to Directive 2008/50/EC (2008). Limit value exceedances are mainly due to emissions and chemical transformation processes, as well as meteorological influences. Wind speed, wind direction and mixing layer height $(\mathrm{MLH})$ are important factors which influence exchange processes of ground level emis25 sions such as the abundance of gaseous pollutants (e.g., $\mathrm{CO}$ and $\mathrm{NO}_{\mathrm{x}}$ concentrations) as well as $\mathrm{PM}_{10}$ and particle size distributions (PSD) (Schäfer et al., 2006, 2011, 2012; Alföldi et al., 2007; Barmpadimos et al., 2011, 2012). If the MLH is located near the
ACPD

14, 2235-2275, 2014

Meterological conditions for air pollution

K. Schäfer et al.

Title Page 
ground, air pollution can be high due to a strongly limited air-mass dilution (Emeis and Schäfer, 2006). Further, temperature and humidity influence secondary gas and particle formation and particle hygroscopic growth (see e.g. Malm and Day, 2001) and thus indirectly influence air pollutant concentrations, including limit value exceedances.

An important study of wintertime aerosol chemical composition and source apportionment of the organic fraction was performed in 2010 in the metropolitan area of Paris (Crippa et al., 2013). It was found that the dominant primary sources are traffic, biomass burning and cooking. The secondary organic aerosol contributes more than $50 \%$ to the total organic mass and includes a highly oxidized factor which is related to 10 diverse sources including wood burning emissions. While it was concluded that particulate pollution in Paris is dominated by regional factors, direct meteorological influences were not discussed in detail.

Here, source apportionment and the role of meteorological conditions (wind, temperature, relative humidity, absolute humidity and MLH) will be discussed to get a deeper

understanding of processes directing PMC, PNC and thus PSD (transport and dilution) as well as secondary particle formation and thus particle composition in the urban area of Augsburg, Germany. The main focus is on organic and ionic PM composition and its relations.

Particle hygroscopic growth and secondary particle formation is believed to be dependent on relative humidity (Malm and Day, 2001; Yue et al., 2009; Wen et al., 2010; Zhang et al., 2010; Zhao et al., 2011; Donateo et al., 2012; El-Metwally et al., 2013; Liu et al., 2013; Wu et al., 2013). As the gas-phase chemistry is influenced by absolute humidity (Malm and Day, 2001; Liu et al., 2013), it will also be considered along with relative humidity. An investigation of both relative and absolute humidity is required since they are temperature dependent in a different way.

Remote sensing can be applied to monitor MLH using lidar or mini-lidar like ceilometers, Sound Detection and Ranging (SODAR) and Radio Acoustic Sounding Systems (RASS). This study focuses on the influences of MLH as monitored with ceilometers and RASS (see Schäfer et al., 2006; Helmis et al., 2012). In the case of Augsburg,
ACPD

$14,2235-2275,2014$

Meterological

conditions for air

pollution

K. Schäfer et al.

Title Page

\section{Abstract}

Conclusions

Tables

14

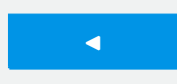

Back

\section{Introduction}

References

Figures

$\rightarrow 1$

$>$

Close
Full Screen / Esc

Printer-friendly Version

Interactive Discussion 
the $\mathrm{MLH}$ is much lower in winter (often below $500 \mathrm{~m}$ ) than in summer (often 1500 to $2300 \mathrm{~m}$ ) as shown by Emeis et al. (2012). During winter, the MLH mostly determines the near-surface concentration of gaseous air pollutants and PSD by up to $50 \%$ in areas that are not influenced by strong emissions and during time periods without strong

5 vertical mixing and advection (Schäfer et al., 2006). It is hypothesised that the MLH and other meteorological parameters also influence PM compound concentration and PSD. That is why a highly polluted winter episode in 2010 , with many limit values exceedances, is analyzed here using a nearly complete range of parameters (only the elemental compounds and isotopic speciation are missing).

10 The speciation of non-refractory particle composition is investigated on the basis of data from Elsasser et al. (2012). The hourly data of air pollutant and PM component concentrations and weather situations during this episode are used to characterize different temporal phases. Source apportionment and organic molecular markers from PM composition are applied to characterize the emission sources which cause high air pollution and limit value exceedances during winter. All data on an hourly-mean basis are applied to determine the weather influences on air pollution by correlation analyses.

It is the objective of this case study to characterize the temporal variation of PM composition during a severe winter pollution episode in an urban area, to define the sources of such an episode and the role of meteorological conditions in PM inorganic and organic components and gaseous pollutants. The high concentrations and limit value exceedances as well as their potential human health impact will be explained.

\section{Measurement methods and data}

\subsection{Study area}

The measurements were performed in Augsburg, Germany, a town with 268000 inhabLech flows northbound perpendicular to the Alps (about $100 \mathrm{~km}$ south of Augsburg)

ACPD

14, 2235-2275, 2014

Meterological

conditions for air pollution

K. Schäfer et al.

Title Page
Abstract

Conclusions

Tables

14

4

Back

\section{Introduction}

References

Figures

DI

Close
Full Screen / Esc

Printer-friendly Version

Interactive Discussion 
towards the Danube in a shallow valley about $10 \mathrm{~km}$ wide and $100 \mathrm{~m}$ deep. Under synoptically calm conditions with weak pressure gradients, we observe light winds from the South at night and from the North to the northeast during the day. For stronger large-scale pressure gradients, the winds do not deviate much from the large-scale 5 synoptic winds (Jacobeit, 1986). The prevailing wind direction in such cases is from the Southwest where there are no big emission sources near Augsburg. A number of measurement sites were operated and are described below.

\subsection{Urban background site}

The measurement site for the determination of particle characteristics was located on the campus of the Augsburg University of Applied Sciences/Hochschule Augsburg (HSA) which is approximately $1 \mathrm{~km}$ to the Southeast of the city centre. Within a radius of $100 \mathrm{~m}$, it is surrounded by campus buildings, a tram depot and a small company. The nearest main roads are to the northeast at a distance of $120 \mathrm{~m}$ and to the Southeast at a distance of $270 \mathrm{~m}$. Within a radius of approximately $200 \mathrm{~m}$, the monitoring site is almost completely surrounded by residential areas, apart from a small park located in to the Northwest. HSA was carefully selected as an urban background site by taking into account the representativeness of a single monitoring station for the exposure of the general population to UFP (Cyrys et al., 2008).

The PM composition was measured continuously by an aerosol mass spectrometer 20 in the $\mathrm{PM}_{1}$ range and by an aethalometer, which measured the $\mathrm{BC}$ (black carbon) content of $\mathrm{PM}_{2.5}$. The aerosol mass spectrometer analysis determined the non-refractory particle components nitrate $\left(\mathrm{NO}_{3}^{-}\right)$, sulphate $\left(\mathrm{SO}_{4}^{2-}\right)$, ammonium $\left(\mathrm{NH}_{4}^{+}\right)$, chloride $\left(\mathrm{Cl}^{-}\right)$ and organic matter. The latter was separated by source apportionment using positive matrix factorization (PMF, see Sect. 3.5) in three factors: OOA - oxygenated organic 25 aerosol (secondary organic factor), HOA - hydrocarbon-like organic aerosol (traffic factor or primary organic factor) and WCOA - wood combustion organic aerosol (wood combustion factor). A high-resolution time-of-flight aerosol mass spectrometer (Aerodyne Research Inc., Billerica, MA, USA; described in DeCarlo et al., 2006) was used 2241
ACPD

14, 2235-2275, 2014

Meterological

conditions for air pollution

K. Schäfer et al.

Title Page

Abstract

Introduction

Conclusions

Tables

References

Figures

14

$\rightarrow$

4

Back

Close

Full Screen / Esc

Printer-friendly Version

Interactive Discussion $\triangleright$

(nteractive Discussion

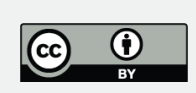


with a collection efficiency of 0.5 for the aerosol mass spectrometry measurements. Additionally, the fragmentation table (Allan et al., 2004) of the aerosol mass spectrometer data analysis tools (SQUIRREL V1.49 and PIKA v.1.08, Sueper, 2010) were modified according to the fragmentation table suggested by Aiken et al. (2008). These measure5 ments and data are described in detail in Elsasser et al. (2012).

PSD were measured by a custom-built particle size spectrometer consisting of twin cylindrical type differential mobility particle sizers, from which PNC in the different size ranges 3-10 (NC3-10), 10-30 (NC10-30), 30-50 (NC30-50), 50-100 (NC50-100), $100-500 \mathrm{~nm}$ (NC100-500) were determined. The general set-up of this instrument has 10 been described in detail elsewhere (Birmili et al., 1999). Size-segregated PMC were calculated from PSD data, assuming a spherical shape of particles and a mean particle density of $1.5 \mathrm{~g} \mathrm{~cm}^{-3}$ (Pitz et al., 2008). $\mathrm{PM}_{10}$ and $\mathrm{PM}_{2.5}$ concentrations were measured by two Tapered Element Oscillating Microbalance/Filter Dynamics Measurement Systems (TEOM Model 1400a, Thermo Fisher Scientific Inc, Franklin, MA, USA). Source apportionment on the basis of PMF is performed with these data also.

The ceilometer CL31 from Vaisala GmbH, Hamburg, Germany is an eye-safe commercial lidar system operated at this station (Münkel, 2007; Münkel et al., 2012). Ceilometers that were originally developed to monitor the cloud height are easy to handle and do not influence the surroundings by sound or light. In the absence of low clouds and precipitation and during scattered clouds, ceilometers can estimate MLH fairly well. Special software for these ceilometers provides routine retrievals of up to 5 lifted layers from vertical profiles (vertical gradient) of laser backscatter density data (Emeis et al., 2007). The ceilometers are able to detect convective layer depths exceeding $2000 \mathrm{~m}$ and nocturnal stable layers down to $50 \mathrm{~m}$. The aerosol structures seen in the lower layers by the ceilometer agree well with the profiles of relative humidity and virtual potential temperature measured by radiosonde and derived MLH (location of strong height gradient of aerosol backscatter density and relative humidity as well as temperature inversion) as shown by Emeis et al. $(2006,2008)$. The radiosonde data from the station Oberschleissheim at the northern edge of Munich (about $50 \mathrm{~km}$ away
ACPD

14, 2235-2275, 2014

Meterological

conditions for air pollution

K. Schäfer et al.

Title Page

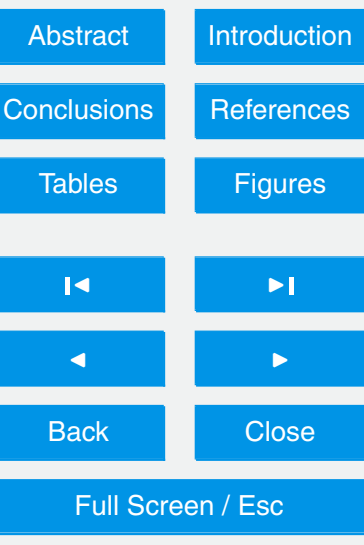

Printer-friendly Version

Interactive Discussion 
from Augsburg) are used for comparison. Radiosonde data does not provide sufficient information as launches only occur twice daily.

\subsection{Air quality monitoring network (LÜB)}

The air pollution data from four stations in Augsburg of the Bavarian air qual5 ity monitoring system/Lufthygienisches Landesüberwachungssystem Bayern (LÜB) were investigated: Bourgesplatz (urban background), Karlstrasse (urban traffic site), Königsplatz (urban traffic site), and LfU (urban edge background) (www.lfu.bayern.de/luft/index.htm\#a0101). The measured concentrations include $\mathrm{PM}_{10}$ and $\mathrm{PM}_{2.5}$ by $\beta$-absorption (FH62-IR,ESM-Anderson Instruments $\mathrm{GmbH}$, Erlangen, 10 Germany), CO by IR-absorption (APMA-360, Horiba, Leichlingen, Germany), NO and $\mathrm{NO}_{2}$ by chemiluminescence (APNA-370, Horiba, Leichlingen, Germany), $\mathrm{O}_{3}$ by UVabsorption (APOA-370, Horiba, Leichlingen, Germany) as well as benzene, toluene and $o$-xylene by gaschromatography (GC-U102 BTX, Siemens, Karlsruhe, Germany) measurements.

\subsection{Rural background site at the airport Augsburg}

Temperature, pressure, relative humidity, wind speed, wind direction, cloud cover, precipitation and sunshine are provided by Germany's National Meteorological Service/Deutscher Wetterdienst (DWD) (Weather Request and Distribution System www. dwd.de/webwerdis). The measurement station is at the Airport Augsburg (AugsburgMühlhausen) about $2 \mathrm{~km}$ north from the northern edge of Augsburg.

\subsection{Urban edge background site}

This site is at the area of the waste treatment plant/Abfallverwertungsanlage Augsburg (AVA) which is located at the northern edge of Augsburg in an industrial area near to the highway A8 and about $2 \mathrm{~km}$ south of Augsburg Airport (urban edge background site). $\mathrm{PM}_{10}, \mathrm{NO}, \mathrm{NO}_{2}$ and $\mathrm{O}_{3}$ were measured at this site using the same methods
ACPD

$14,2235-2275,2014$

Meterological

conditions for air

pollution

K. Schäfer et al.

Title Page

Abstract

Introduction

Conclusions

References

Tables

Figures

14

$\rightarrow 1$

4

Back

Close

Full Screen / Esc

Printer-friendly Version

Interactive Discussion 
described in Sect. 2.3 and $\mathrm{CO}$ is detected precisely by fluorescence measurements (AL5001, Aerolaser GmbH, Garmisch-Partenkirchen, Germany).

The vertical profiles of wind, dispersion parameters and temperature up to $500 \mathrm{~m}$ are continuously measured during stable or neutral atmospheric conditions by a RASS 5 from Metek GmbH, Elmshorn, Germany to determine MLH. MLH by RASS is determined from the inversion of the temperature profile. For well-mixed conditions during the afternoon hours, information for determination of the MLH is unavailable. The temperature measurements agree well with the aerosol structures seen in the lower layers by the ceilometer. These characteristics of ceilometers and RASS for the automatic 10 and continuous observation of MLH are summarized in Emeis et al. (2004), Emeis et al. (2009) and Emeis et al. (2012). In this study, MLH data from ceilometer measurements at the urban background site are taken if no RASS results are available. Further, ceilometer MLH results are used if the MLH is lower than the cloud lower boundary and if no fog is detected. If this is not the case, the available RASS data are used.

\section{Analysis methods}

\subsection{Selection of analyses period}

A one year time series of hourly-mean values of $\mathrm{PM}_{2.5}$ concentration measurements at the urban background site HSA from 01 October 2009 to 30 September 2010 is shown in Fig. 1. The higher concentration level during winter and the $\mathrm{PM}_{2.5}$ concentration peaks $\left(110.7 \mathrm{\mu g} \mathrm{m}^{-3}\right.$ maximum on 11 February 2010) are clearly visible. Further, twelve limit value exceedances of $\mathrm{PM}_{10}$ with daily mean concentrations up to $96 \mathrm{\mu gm}^{-3}$ at the urban edge background site, $\mathrm{LfU}$, were detected during winter ( $\mathrm{no} \mathrm{NO}_{2}$ limit value exceedances). High $\mathrm{PM}_{2.5}$ concentrations during winter and the large number of $\mathrm{PM}_{10}$ limit value exceedances motivate the study of the period from 31 January, 00:00 CET

\section{ACPD}

14, 2235-2275, 2014

\section{Meterological \\ conditions for air pollution}

K. Schäfer et al.

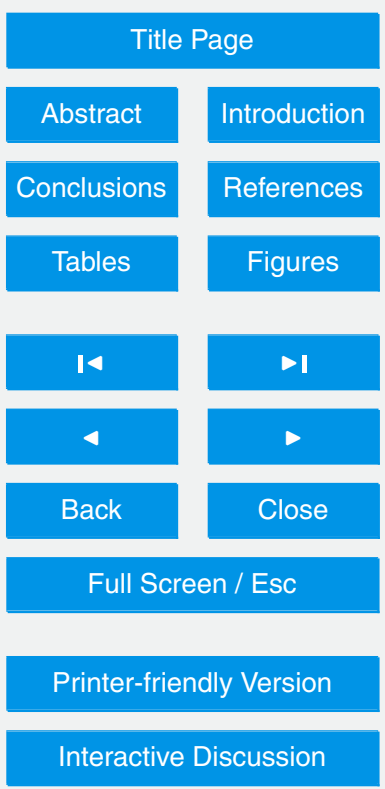




\subsection{Comparison of measurement results at different sites}

As the chemical characterization of PM was measured without gaseous pollutants at the urban background site HSA, it was necessary to take data for all gaseous pollutants from another urban background site. The hourly-mean values of measurement results 5 at Bourgesplatz (LÜB), LfU (LÜB), urban background site (HSA) and urban edge background site (AVA) were used since similar temporal variations were found there (see Table 1 as well as Fig. S1).

The location of Bourgesplatz is very similar to the urban background site HSA so that $\mathrm{NO}$ and $\mathrm{NO}_{\mathrm{x}}$ were used from this site (higher $\mathrm{NO}$ and $\mathrm{NO}_{\mathrm{x}}$ concentrations than at AVA and LfU). Unfortunately, the other pollutants are not measured here so that the CO, $\mathrm{O}_{3}$, benzene, toluene and $o$-xylene concentrations were taken from the urban edge background site LfU (higher $\mathrm{CO}$ and $\mathrm{O}_{3}$ concentrations than at the site AVA). $\mathrm{PM}_{2.5}$ and $\mathrm{PM}_{10}$ concentrations were used from the urban background site HSA where all the other particle parameters were measured.

\subsection{Definition of different temporal phases}

As also done by Birmili et al. (2009), different temporal phases were defined on the basis of

- PMC levels

- Concentrations of organic and inorganic PM components and their relations

- Different PMF factors determined in aerosol mass spectrometer data analysis

- Weather characteristics (precipitation, i.e. wet deposition, wind direction, wind speed and $\mathrm{MLH}$, i.e. air mass transport and dilution, temperature as well as relative humidity and absolute humidity, i.e. secondary aerosol formation conditions).

These criteria allowed the definition of 10 temporal phases (see Figs. 2 and S1). The

phases are characterized by composition and meteorological parameters (quantita-
ACPD

14, 2235-2275, 2014

Meterological

conditions for air

pollution

K. Schäfer et al.

Title Page 
tively also) in Table S1 in the supplements. During the whole study period, the total variations in the concentrations of $\mathrm{PM}_{1}, \mathrm{PM}_{2.5}$ and $\mathrm{PM}_{10}$ as well as the chemical $\mathrm{PM}_{1}$ components are one order of magnitude, temperatures are from -12 to $+13^{\circ} \mathrm{C}$ and wind speeds are from 0 to $14 \mathrm{~ms}^{-1}$.

\section{3.4 Correlations of all air pollutants and meteorological parameters}

Pearson correlation coefficients were calculated between all pollutants and of each pollutant with all meteorological parameters (including the PMF analyses results, see Sect. 3.5) using the standardized data (see also Wen et al., 2010; Wu et al., 2013) on the basis of hourly-mean values during the period from 31 January, 00:00 CET to 12 March 2010, 24:00 CET (984 data points). The correlation coefficient values are given in Tables $\mathrm{S} 2$ and $\mathrm{S} 3$ in the supplements. $\mathrm{SO}_{2}$ concentrations are not considered because the concentrations are normally near the detection limit of the instruments.

The correlation coefficients were then clustered using a hierarchical clustering analysis with the Ward method. Heatmaps, including a dendrogram on the columns and rows, help distinguish the results. Clusters between rows (columns) can be identified by reading the dendrogram from right to left (bottom to top). The length of the branches at each clade represents the similarity between cluster members (e.g., the longer the branch, the greater the difference). The correlation calculations also include the $p$ value for each correlation. The hypothesis test to obtain the $p$ values is testing if any correlation exists at all.

Wind polar plots were used where the wind direction is expressed as polar coordinates (circles) and the wind speed by colours. The magnitude is given in the horizontal and vertical axis and corresponds to the standardized values for each pollutant ("standardized" means that all pollutants are forced to have average $=0$ and standard devi-
ACPD

$14,2235-2275,2014$

Meterological

conditions for air

pollution

K. Schäfer et al.

Title Page

Abstract

Introduction

Conclusions

References

Tables

Figures

14

$\rightarrow 1$

4

Back

Close

Full Screen / Esc

Printer-friendly Version

Interactive Discussion 


\subsection{Positive matrix factorization (PMF) analyses}

PMF is a bilinear unmixing model which provides the opportunity to describe the measured organic fraction/matter by the aerosol mass spectrometer as a linear combination of factors. A factor contains a constant mass spectrum (factor profile) and a variable 5 contribution with time (factor strength). The factors represent physically positive concentrations. A detailed description of the PMF model and analysis can be found in the studies of Lanz et al. (2007), Ulbrich et al. (2009), and Paatero et al. (1994, 1997). The PMF analysis followed the procedure described by Ulbrich et al. (2009) and is discussed in detail for this data in Elsasser et al. (2012). The PMF analysis obtained

10 a three-factor solution performed by FPEAK 0.2 with 14285 time points and 268 massto-charge ratios $(\mathrm{m} / \mathrm{z})$ from $\mathrm{m} / \mathrm{z}=12$ to 300 . Normally, these factors are dominated by sources. In this three-factor solution, factors are found related to freshly emitted HOA, which is related to traffic, and WCOA. Additionally, one non-source related factor could be calculated for OOA, which is mainly of secondary origin.

The PMF method was also applied in Augsburg to the PSD data to identify possible particle sources (Gu et al., 2011). In this study, seven different source profiles were determined and assigned to the following particle sources, given the corresponding maximum size for PNC / PMC in the brackets: nucleation $(8 \mathrm{~nm} /-)$, fresh traffic $(20 \mathrm{~nm} /-)$, aged traffic $(40 \mathrm{~nm} / 200 \mathrm{~nm})$, stationary combustion $(80 \mathrm{~nm} / 300 \mathrm{~nm})$, secondary aerosol $(350 \mathrm{~nm} / 500 \mathrm{~nm})$, long-range dust $(-/ 2000 \mathrm{~nm})$ and resuspended dust $(-/ 4000 \mathrm{~nm})$. However, we utilized PSD data covering 64 size bins ranging from $3.8 \mathrm{~nm}$ to $8.8 \mu \mathrm{m}$ as input data. Since no measurement error was available for PSD, the uncertainties were calculated according to empirical equations described in Gu et al. (2011). In our study, only PSD data in the size range from $3.8 \mathrm{~nm}$ to $800 \mathrm{~nm}$ were available as the Aerodynamic Particle Sizer (Model 3321, TSI, Shoreview, MN, US) was not in operation due to maintenance and consequently data in the size ranges $850 \mathrm{~nm}-10 \mu \mathrm{m}$ and the factors long-range dust and re-suspended dust are missing.
ACPD

14, 2235-2275, 2014

Meterological

conditions for air pollution

K. Schäfer et al.

Title Page
Abstract

Conclusions

Tables

14

4

Back

\section{Introduction}

References

Figures

$\rightarrow 1$

Close
Full Screen / Esc

Printer-friendly Version

Interactive Discussion 


\section{Results}

\subsection{Temporal variations}

The temporal variation of concentrations of some PM chemical fractions ( $\mathrm{HOA}$, WCOA and $\mathrm{OOA}$ ) and $\mathrm{CO}$ together with the meteorological parameters (temperature, absolute 5 humidity, relative humidity, wind speed and MLH) during the measurement campaign is shown in Fig. 3. The wind speed (dilution and transport), humidity (particle growing) and MLH (mixing volume) show a significant influence upon the concentration of these compounds: low concentrations during high wind speeds/high MLHs/low relative humidity/high absolute humidity and high concentrations during low wind speeds/low $\mathrm{MLHs} /$ high relative humidity/low absolute humidity. Rain or snow occurred in all phases during certain time spans except phase 1. In contrast, the concentrations of NC3-10 (number concentrations of nucleation mode particles which are defined in the size range $3 \mathrm{~nm}-10 \mathrm{~nm}$ ), NC10-30 (number concentrations of Aitken mode particles which are defined in the size range $10 \mathrm{~nm}-100 \mathrm{~nm}$ ) and fresh traffic aerosol are only weakly dependent on meteorological parameters. This is also shown by all Pearson correlation coefficients in Tables S2 and S3 in the supplements.

\subsection{Cross-correlations of each air pollutant and PM component}

High $\mathrm{CO}$ as well as $\mathrm{NO}_{\mathrm{x}}$ and benzene concentrations are indicators of heavy air pollution. $\mathrm{CO}$ and benzene concentrations are correlated strongly with $\mathrm{HOA}$, soot $(\mathrm{BC})$ and NC100-500, i.e. accumulation mode particles which are formed in the atmosphere and defined in the size range $100 \mathrm{~nm}-1 \mu \mathrm{m}$ (see Fig. 4 as well as all Pearson correlation coefficients in the supplements Table S2). Figure 4 shows a heatmap of the Pearson cross-correlations between all air pollutants (correlations equal to 1 are coloured in white), including dendrograms for rows and columns (obtained with hierarchical clustering). This presentation is "diagonally symmetric" in that what is shown on the topdiagonal is the same as in the low-diagonal. There are no strong correlations of NO,
ACPD

14, 2235-2275, 2014

Meterological

conditions for air

pollution

K. Schäfer et al.

Title Page 
$\mathrm{NO}_{2}$ or $\mathrm{NO}_{\mathrm{x}}$ with $\mathrm{NO}_{3}^{-} \cdot \mathrm{O}_{3}$ shows negative correlations with all pollutants, sometimes higher than 0.5 as with $\mathrm{CO}$, benzene, $\mathrm{NO}_{2}, \mathrm{HOA}, \mathrm{BC}$ and NC100-500. Significant positive correlations between the pollutants (see Table S2 also) are found within these clusters:

(a) $\mathrm{NO}_{3}^{-}, \mathrm{SO}_{4}^{2-}, \mathrm{NH}_{4}^{+}, \mathrm{OOA}$, secondary aerosol, WCOA, stationary combustion aerosol, $\mathrm{PM}_{2.5}$, and $\mathrm{PM}_{10}$, i.e. secondary pollutants and fine particles, as well as

(b) $\mathrm{CO}$, benzene, $\mathrm{HOA}, \mathrm{BC}$ and $\mathrm{NC} 100-500$, i.e. primary pollutants and accumulation mode particles.

10 There seems to be a third cluster containing $\mathrm{NO}, \mathrm{NO}_{2}, \mathrm{NO}_{\mathrm{x}}, O$-xylene, toluene, aged traffic aerosol NC30-50 and NC50-100 but the correlations are mostly lower than 0.8. Nucleation aerosol, fresh traffic aerosol, NC3-10 and NC10-30 are also correlated. This clustering also suggests that there are similar temporal variations of the pollutants in each of the two clusters.

\subsection{Correlations of pollutants with meteorological parameters}

The results of hierarchical clustering of correlations between pollutants and meteorological parameters during the measurement period (each temporal phase and total period) are shown in Fig. 5 including the dendrogram on the columns and rows. Due to the positive correlation of absolute humidity and temperature, there is a similar negative correlation of $\mathrm{OOA}$, secondary aerosol, $\mathrm{NO}_{3}^{-}, \mathrm{SO}_{4}^{2-}, \mathrm{NH}_{4}^{+}, \mathrm{PM}_{2.5}, \mathrm{PM}_{10}$ and stationary combustion aerosol (cluster "secondary pollutants and fine particles") and NC100-500 with temperature and absolute humidity. Other pollutants are nearly independent from absolute humidity (see Fig. 6 also).

Phase 4 shows opposite relations in comparison to all other phases as mentioned in 25 Sect. 3.3 and will be discussed later (Sect. 4.4). Ozone correlations are different to the correlations shown in Fig. 4.
ACPD

$14,2235-2275,2014$

Meterological

conditions for air

pollution

K. Schäfer et al.

Title Page

Abstract

Introduction

Conclusions

References

Tables

Figures

14

DI

4

Back

Close

Full Screen / Esc

Printer-friendly Version

Interactive Discussion 
We observe the following significant correlations ( $p$ value $<0.05)$ between pollutants and meteorological parameters (see all Pearson correlation coefficients in Table S3 in the supplements also):

- Significant correlations with all meteorological parameters for $\mathrm{NO}_{3}^{-}, \mathrm{SO}_{4}^{2-}$, and $\mathrm{NH}_{4}^{+}$, OOA, HOA, WCOA, $\mathrm{NO}_{2}$, benzene, o-xylene, $\mathrm{PM}_{2.5}, \mathrm{PM}_{10}, \mathrm{NC} 30-50$, NC50-100, NC100-500, aged traffic, secondary aerosol and stationary combustion aerosol i.e. the secondary pollutants mainly (except HOA, benzene, $O$ xylene).

- Significant correlations with relative humidity, absolute humidity, wind speed and $\mathrm{MLH}$ (but not with temperature) for $\mathrm{NO}, \mathrm{NO}_{\mathrm{x}}$ and toluene.

- Significant correlations with temperature, relative humidity, wind speed and MLH (but not with absolute humidity) for BC, CO, NC3-10 and nucleation aerosol, i.e. primary pollutants.

- Significant correlations with relative humidity, wind speed and MLH (but not with temperature and absolute humidity) for NC10-30, i.e. Aitken mode particles.

- Significant correlation with wind speed only for fresh traffic aerosol.

In Fig. 5, the dendrogram on the columns shows a clustering of the phases. It is difficult to conclude from this dendrogram general groups for the correlations of air pollutant concentrations with the meteorological parameters. If one is looking for a grouping as a first step, the dendrograms show that phase 4 is a special case and cannot be included in a group. Otherwise, three groups can be identified from the correlations with single meteorological parameters, which are shown in Fig. 6 together with phase 4 and the total measurement period, and can be characterised as follows:

1. Very low $P M C\left(P M_{1}, P M_{2.5}, P M_{10}\right)$ with high organic content in $P_{1}$. Some peak
ACPD

$14,2235-2275,2014$

Meterological

conditions for air

pollution

K. Schäfer et al.

Title Page

Abstract

Introduction

Conclusions

References

Tables

Figures

14

$>1$

4

Back

Close

Full Screen / Esc

Printer-friendly Version

Interactive Discussion 
est wind speeds (up to $14 \mathrm{~ms}^{-1}$ ). Wind directions from west-southwest to southsoutheast. Phase 1, 2 and 7.

2. High $\mathrm{PMC}\left(\mathrm{PM}_{1}, \mathrm{PM}_{2.5}, \mathrm{PM}_{10}\right)$ with higher organic and $\mathrm{SO}_{4}^{2-}$ content as well as high $\mathrm{NO}_{3}^{-}$content in $\mathrm{PM}_{1}$ concentration peaks. Highest $\mathrm{CO}, \mathrm{NO}$ and $\mathrm{NO}_{\mathrm{x}}$ concentrations. Temperatures mostly below $0^{\circ} \mathrm{C}$ down to $-12^{\circ} \mathrm{C}$. Lowest wind speeds (below $7 \mathrm{~ms}^{-1}$ ). All wind directions. Phases 5, 6, and 10.

3. Low to mean $\mathrm{PMC}\left(\mathrm{PM}_{1}, \mathrm{PM}_{2.5}, \mathrm{PM}_{10}\right)$ with higher $\mathrm{NO}_{3}^{-}$content in $\mathrm{PM}_{1}$. Some peak $\mathrm{CO}, \mathrm{NO}$ and $\mathrm{NO}_{\mathrm{x}}$ concentrations. Temperatures from -12 up to $+7^{\circ} \mathrm{C}$. Wind speeds between 1 and $11 \mathrm{~ms}^{-1}$. Wind directions around north (from westsouthwest to east). Phases 3, 8, and 9.

These groups are different in PM composition and concentrations, $\mathrm{CO}, \mathrm{NO}$ and $\mathrm{NO}_{\mathrm{x}}$ concentrations, temperature, wind speed and wind direction. In phase 4, continuous snowfall occurred and is not considered to be typical. Otherwise, the $\mathrm{O}_{3}$ correlations are similar within the three groups.

The dependencies of concentrations on wind direction and wind speed are shown in the plots of Fig. 7. Maximum concentrations are found during wind directions from the Southeast, which are characterised by low wind speeds (often wind speed $<1 \mathrm{~ms}^{-1}$ ), for "Primary pollutants" (shown for $\mathrm{CO}$ and $\mathrm{HOA}$ in Fig. 7) and $\mathrm{NO}, \mathrm{NO}_{2}, \mathrm{NO}_{\mathrm{x}}, \mathrm{o}$-xylene, toluene, NC30-50, and NC50-100, i.e. the Aitken mode particles. There is no wind direction dependence for "Secondary pollutants" and NC3-10, i.e. the nucleation mode particles, and NC10-30. Wind speeds lower than $3 \mathrm{~ms}^{-1}$ during the events of high concentrations correspond with a low MLH (see Fig. 3). As the compounds are measured at different sites, it can be concluded that wind speed and MLH influence the concentrations of primary pollutants, in addition to local emission sources. These findings agree statement by Tai et al. (2010) and Tandon et al. (2010) that up to $50 \%$ of the particulate variability can be explained with temperature, relative humidity, precipitation, and circulation (wind and MLH).

ACPD

$14,2235-2275,2014$

Meterological

conditions for air

pollution

K. Schäfer et al.

Title Page

Abstract

Introduction

Conclusions

References

Tables

Figures

14

$>1$

4

Back

Close

Full Screen / Esc

Printer-friendly Version

Interactive Discussion
$>$

(n)

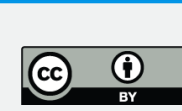


The comparison of temporal variations of the pollutants during the total measurement period found that a shift in the concentrations of the pollutants by one or two hours against the meteorological parameters provides higher correlation coefficients and very similar temporal variations. This means that after a change in the weather 5 characteristics, the concentrations of pollutants follow within one to two hours of this weather change (see also Tandon et al., 2010).

\subsection{Special phase}

Quantitative analyses of the pronounced phase 4 (see Fig. 5) are discussed in detail here. Phase 4 (one-day-event with strongest PMC increase during "wet" snow fall) is 10 also shown in Fig. 6 since it is not included in the cluster analyses for grouping (see Sect. 4.3). Wind speed is lowest during the observation period which is a main influence leading to high concentrations. Wind speeds are from 0.5 to $5 \mathrm{~m} \mathrm{~s}^{-1}$ and wind directions are from west-northwest and north-northwest. Temperatures are from -9 to $-4{ }^{\circ} \mathrm{C}$.

During this event, higher WCOA, OOA, HOA and $\mathrm{SO}_{4}^{2-}$ contents as well as high $15 \mathrm{CO}, \mathrm{NO}$ and $\mathrm{NO}_{x}$ concentrations existed. The correlations between all pollutants (see Fig. 8) are higher than the mean (see Fig. 4 and in the supplements Table S2, except $\mathrm{NO}_{3}^{-}$and $\mathrm{NH}_{4}^{+}$), implying nearly all pollutants show this strong concentration increase. The clustering provides a different result than for the other phases: a cluster including Aitken and accumulation mode particles (NC30-50, NC50-100 and NC100-500), 20 aged traffic aerosol, $\mathrm{NO}_{3}^{-}$and $\mathrm{NH}_{4}^{+}$with low correlations and no strong concentration increase as well as a cluster with all local and regional compounds (benzene, OOA, WCOA, o-xylene, HOA, toluene, $\mathrm{BC}$, secondary aerosol, $\mathrm{CO}, \mathrm{PM}_{10}, \mathrm{PM}_{2.5}$ including $\mathrm{SO}_{4}^{2-}$, nucleation aerosol, NC3-10, fresh traffic aerosol, $\mathrm{NC} 10-30, \mathrm{NO}_{\mathrm{x}}, \mathrm{NO}$ and $\mathrm{NO}_{2}$ ) with lower correlations.

25 High positive correlations of all pollutants (except $\mathrm{NO}_{3}^{-}$) with temperature, wind speed, MLH (all these correlations are normally negative) and relative humidity were found. The positive correlations most probably are caused by the short time span of
ACPD

$14,2235-2275,2014$

Meterological

conditions for air pollution

K. Schäfer et al.

Title Page 
this phase (one day only), i.e. the diurnal variation of temperature, wind speed and $\mathrm{MLH}$ which is in agreement with the concentration increase.

\subsection{Positive matrix factorization (PMF) comparison}

The factor secondary aerosol from PMF analyses of PSD data (see also mass con5 centrations in Fig. S2) is maximum during the time periods 5-20 February 2010 and 12 March 2010. The nucleation aerosol factor is highly variable during the study period and smallest in mass concentration. The factor fresh traffic aerosol and the factor aged traffic aerosol, which is higher than the factor fresh traffic aerosol, are maximum during daytime but of less variability during the study period and of lesser magnitude than the secondary aerosol factor. The stationary combustion aerosol factor is dependent on temperature but is also weaker than the secondary aerosol factor.

The comparison of the different factors from PMF analyses of PSD data with those from PMF analyses of $\mathrm{PM}_{1}$ composition shows that the factor secondary aerosol is maximum during those time periods when the $\mathrm{PM}_{1}$ mass concentration fractions (see Fig. 2) are maximum (phase 4 and group "High concentrations"). Finally, the same

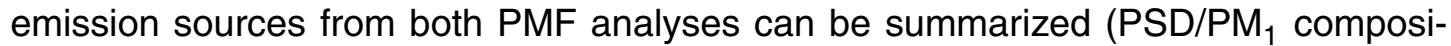
tion) as shown in Fig. S2:

- fresh traffic and aged traffic aerosol factor/BC and HOA (traffic factor or primary organic factor),

- stationary combustion aerosol factor/BC and WCOA (wood combustion factor),

- secondary aerosol factor/OOA (secondary organic factor).

Further, the secondary aerosol factor is correlated with $\mathrm{PM}_{2.5}$ and $\mathrm{PM}_{10}$, stationary combustion aerosol factor with NC100-500, aged traffic aerosol factor with NC50-100 and NC30-50, fresh traffic aerosol factor with NC10-30 and nucleation aerosol factor
ACPD

14, 2235-2275, 2014

Meterological

conditions for air

pollution

K. Schäfer et al.

Title Page

Abstract

Introduction

Conclusions

References

Tables

Figures

14

$>1$

4

Back

Close

Full Screen / Esc

Printer-friendly Version

Interactive Discussion 


\section{Summary, discussion and conclusions}

\subsection{Emissions}

The temporal variations of air pollutants and PM composition as well as meteorological parameters during this high air pollution winter episode on the basis of hourly-

5 mean data show characteristic temporal phases. These variations are mainly caused by weather changes as emission variation could never influence the concentrations of air pollutants and PM components to the degree (one order of magnitude) found during this study period. Source apportionment from $\mathrm{PM}_{1}$ composition as well as from PSD of $\mathrm{PM}_{2.5}$ provided the main emission sources: road traffic as well as stationary and wood 10 combustion (see Fig. S2). But the concentrations of the secondary aerosol factor are very often the highest ones as also found in winter 2010 in Paris (Crippa et al., 2013). Further, the cross-correlations of each air pollutant and PM component show two clusters: "secondary pollutants of $\mathrm{PM}_{1}$ and fine particles" as well as "primary pollutants and accumulation mode particles".

\section{$15 \quad 5.2$ Transport}

The understanding of processes directing PMC, PNC and thus PSD as well as particle composition and thus secondary particle formation requires knowledge of the wind, $\mathrm{MLH}$, humidity and temperature. The role of dilution and transport (wind speed), the mixing volume (MLH), particle growth (humidity), and secondary particle formation (temperature, humidity) could be shown quantitatively on the basis of correlation analyses. The two clusters, "secondary pollutants of $\mathrm{PM}_{1}$ and fine particles" as well as "primary pollutants and accumulation mode particles" were also found by studying the correlations between the concentration of each pollutant and meteorological parameters. Wind speed, MLH and relative humidity are important for primary pollutants as well as temperature and humidity for secondary pollutants. The investigation of the

\section{Meterological conditions for air pollution}

K. Schäfer et al.

Title Page 
dependence of pollutant concentrations on wind direction provides information about the dominant role of wind speed and MLH.

\subsection{Ozone}

The sign of the correlation of ozone with the other air pollutants (mostly negative) and 5 meteorological parameters is always opposite to the corresponding sign of all other pollutants. This is related to the photochemical formation of ozone - it is a secondary pollutant which is mainly formed from $\mathrm{NO}, \mathrm{NO}_{2}$ and volatile organic compounds - as well as titration.

\subsection{Influence of meteorological parameters}

$10 \mathrm{OOA}$, secondary aerosol, $\mathrm{NO}_{3}^{-}, \mathrm{SO}_{4}^{2-}, \mathrm{NH}_{4}^{+}, \mathrm{PM}_{2.5}, \mathrm{PM}_{10}$ and stationary combustion aerosol (cluster "secondary pollutants and fine particles") and NC100-500 show low concentrations during high absolute humidity and vice versa. Other pollutants show nearly no dependence on absolute humidity.

\subsection{Special phase}

15 Phase 4 is a short-term event with a strong PMC (particle mass concentration) increase during "wet" snow fall. Higher $\mathrm{SO}_{4}^{2-}$ and WCOA contents in comparison to the other phases exist but $\mathrm{NO}_{3}^{-}$is not enhanced.

\subsection{Conclusions}

During high air pollution events, wind, mixing layer height, humidity, and temperature 20 mainly influence the mass concentration of gaseous air pollutants and PM compounds as well as the particle size distribution, but varies during different weather conditions. The role of different emission sources is less important, meaning that the hypothesis that a dominant influence of meteorological parameters exists not only for gaseous pol-

\section{Meterological conditions for air pollution}

K. Schäfer et al.

\section{Title Page}


lutants but also for PM compounds and the particle size distribution has been demonstrated. This is shown from two different source apportionment analyses (PMF for $\mathrm{PM}_{1}$ composition and $\mathrm{PM}_{2.5}$ size distribution). The $\mathrm{PM}_{10}$ limit value exceedances are caused mainly by the meteorological influences and not only by the emissions. On the other 5 hand, the mass concentration of toluene, NO, NC3-10 (nucleation mode particles), NC10-30, NC30-50 (Aitken mode particles) and fresh traffic aerosols are only weakly dependent on meteorological parameters and seem to be driven by emissions. A further underlying mechanism is that during relatively "clean" conditions, there are less particle surfaces which act as a sink for nucleation particles and to a lesser extent for 10 Aitken mode particles (e.g., via coagulation).

Three typical groups of meteorological influences are identified. The first is low to average mass concentrations $\left(\mathrm{PM}_{1}, \mathrm{PM}_{2.5}, \mathrm{PM}_{10}\right)$ with higher organic and $\mathrm{SO}_{4}^{2-}$ content as well as high $\mathrm{NO}_{3}^{-}$content in $\mathrm{PM}_{1}$ concentration peaks together with peak $\mathrm{CO}$, NO and $\mathrm{NO}_{\mathrm{x}}$ concentrations occurring during varying temperature, wind speeds between 151 and $11 \mathrm{~m} \mathrm{~s}^{-1}$ and northerly wind directions (influence of city centre, but not for NO and $\left.\mathrm{NO}_{\mathrm{x}}\right)$. The second is high mass concentrations $\left(\mathrm{PM}_{1}, \mathrm{PM}_{2.5}, \mathrm{PM}_{10}\right.$ and 6 of the 8 $\mathrm{PM}_{10}$ limit value exceedances) with higher organic and $\mathrm{SO}_{4}^{2-}$ content as well as high $\mathrm{NO}_{3}^{-}$content in $\mathrm{PM}_{1}$ concentration peaks accompanied by the highest detected $\mathrm{CO}$, $\mathrm{NO}$ and $\mathrm{NO}_{x}$ concentrations during temperatures mostly below $0^{\circ} \mathrm{C}$, the lowest wind speeds and often south-easterly wind directions. The third is very low mass concentrations $\left(\mathrm{PM}_{1}, \mathrm{PM}_{2.5}, \mathrm{PM}_{10}\right)$ with high organic content in $\mathrm{PM}_{1}$ with some peak $\mathrm{CO}, \mathrm{NO}$ and $\mathrm{NO}_{x}$ concentrations during the highest temperatures (up to $+13^{\circ} \mathrm{C}$ ), the highest wind speeds (up to $14 \mathrm{~m} \mathrm{~s}^{-1}$ ) and wind directions from west-southwest to south-southeast.

Two clusters - primary and secondary pollutants - are important since the influence of the meteorological parameters determined by correlations is different (but always significant): wind speed (negative), wind direction, mixing layer height (negative) and relative humidity (positive) influence primary pollutants and accumulation mode particles as well as temperature (negative), absolute humidity (negative) and relative humidity (positive) influence secondary pollutants and fine particles. Correlations indicate

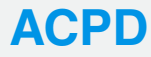

$14,2235-2275,2014$

Meterological conditions for air pollution

K. Schäfer et al.

Title Page

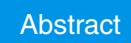

Introduction

Conclusions

References

Tables

Figures

14

- I

4

Back

Close

Full Screen / Esc

Printer-friendly Version

Interactive Discussion 
that secondary pollutants depend on absolute humidity and primary pollutants on relative humidity.

Ultra-fine particle (particle diameter $<100 \mathrm{~nm}$ ) exposures, which are of high health risk, are only weakly dependent on meteorological parameters and are thus influenced 5 by emissions and secondary particle formation processes.

The results presented here concerning high air pollutant concentrations contribute to general information for aiding epidemiological investigations performed in this urban area (Cyrys et al., 2008; Gu et al., 2012) and for the development of emission reduction measures.

10 Supplementary material related to this article is available online at http://www.atmos-chem-phys-discuss.net/14/2235/2014/ acpd-14-2235-2014-supplement.pdf.

Acknowledgements. We like to thank our colleagues C. Jahn, R. Friedl and M. Hoffmann (KIT/IMK-IFU) for effective cooperation during the measurement campaign, Christoph Münkel 15 (Vaisala $\mathrm{GmbH}$, Hamburg, Germany) for cooperation within the frame of MLH determination from ceilometer data and Michael Tuma (KIT/IMK-IFU) during his internship for careful $\mathrm{MLH}$ analyses from ceilometer and RASS measurements. We are very thankful for the the language corrections (both grammar and comprehensibility) of the manuscript by R. Foreman (KIT/IMK-IFU).

The service charges for this open access publication have been covered by a Research Centre of the Helmholtz Association.

\section{References} brich, I. M., Mohr, C., Kimmel, J. R., Sueper, D., Zhang, Q., Sun, Y., Trimborn, A., North-

\section{Meterological conditions for air pollution}

K. Schäfer et al.

\section{Title Page}


way, M., Ziemann, P. J., Canagaratna, M. R., Onasch, T. B., Alfarra, R., Prévôt, A. S. H., Dommen, J., Duplissy, J., Metzger, A., Baltensperger, U., and Jimenez, J. L.: O/C and OM/OC ratios of primary, secondary, and ambient organic aerosols with high resolution time-of-flight aerosol mass spectrometry, Environ. Sci. Technol., 42, 4478-4485, 2008.

5 Alföldy, B., Osán, J., Tóth, Z., Török, S., Harbusch, A., Jahn, C., Emeis, S., and Schäfer, K.: Aerosol optical depth, aerosol composition and air pollution during summer and winter conditions in Budapest, Sci. Total Environ., 383, 141-163, 2007.

Allan, J. D., Delia, A. E., Coe, H., Bower, K. N., Alfarra, M. R., Jimenez, J. L., Middlebrook, A. M., Drewnick, F., Onasch, T. B., Canagaratna, M. R., Jayne, J. T., and Worsnop, D. R.: A generalised method for the extraction of chemically resolved mass spectra from Aerodyne aerosol mass spectrometer data, J. Aerosol Sci., 35, 909-922, 2004.

Barmpadimos, I., Hueglin, C., Keller, J., Henne, S., and Prévôt, A. S. H.: Influence of meteorology on $\mathrm{PM}_{10}$ trends and variability in Switzerland from 1991 to 2008, Atmos. Chem. Phys., 11, 1813-1835, doi:10.5194/acp-11-1813-2011, 2011.

Barmpadimos, I., Keller, J., Oderbolz, D., Hueglin, C., and Prévôt, A. S. H.: One decade of parallel fine $\left(\mathrm{PM}_{2.5}\right)$ and coarse $\left(\mathrm{PM}_{10}-\mathrm{PM}_{2.5} \mathrm{q}\right)$ particulate matter measurements in Europe: trends and variability, Atmos. Chem. Phys., 12, 3189-3203, doi:10.5194/acp-12-3189-2012, 2012.

Birmili, W., Stratmann, F., and Wiedensohler, A.: Design of a DMA-based size spectrometer for a large particle size range and stable operation, J. Aerosol Sci. 30, 549-553, 1999.

Birmili, W., Weinhold, K., Nordmann, S., Wiedensohler, A., Spindler, G., Müller, K., Herrmann, H., Gnauk, T., Pitz, M., Cyrys, J., Flentje, H., Nickel, C., Kuhlbusch, T. A. J. Löschau, G., Haase, D., Meinhardt, F., Schwerin, A., Ries, L., and Wirtz, K.: Atmospheric aerosol measurements in the German Ultrafine Aerosol Network (GUAN): Part 1 - soot and particle number size distributions, Gefahrst. Reinhalt. L., 69, 137-145, 2009.

Crippa, M., DeCarlo, P. F., Slowik, J. G., Mohr, C., Heringa, M. F., Chirico, R., Poulain, L., Freutel, F., Sciare, J., Cozic, J., Di Marco, C. F., Elsasser, M., Nicolas, J. B., Marchand, N., Abidi, E., Wiedensohler, A., Drewnick, F., Schneider, J., Borrmann, S., Nemitz, E., Zimmermann, R., Jaffrezo, J.-L., Prévôt, A. S. H., and Baltensperger, U.: Wintertime aerosol chemical composition and source apportionment of the organic fraction in the metropolitan area of Paris, Atmos. Chem. Phys., 13, 961-981, doi:10.5194/acp-13-961-2013, 2013.
ACPD

14, 2235-2275, 2014

Meterological

conditions for air

pollution

K. Schäfer et al.

Title Page

Abstract

Introduction

Conclusions

References

Tables

Figures

14

$>1$

4

Back

$>$

Close

Full Screen / Esc

Printer-friendly Version

Interactive Discussion 
Cyrys, J., Pitz, M., Heinrich, H., Wichmann, H. E., and Peters, A.: Spatial and temporal variation of particle number concentration in Augsburg, Germany, Sci. Total Environ., 401, 168-175, 2008.

DeCarlo, P. F., Dunlea, E. J., Kimmel, J. R., Aiken, A. C., Sueper, D., Crounse, J., Wennberg, P. O., Emmons, L., Shinozuka, Y., Clarke, A., Zhou, J., Tomlinson, J., Collins, D. R., Knapp, D., Weinheimer, A. J., Montzka, D. D., Campos, T., and Jimenez, J. L.: Fast airborne aerosol size and chemistry measurements above Mexico City and Central Mexico during the MILAGRO campaign, Atmos. Chem. Phys., 8, 4027-4048, doi:10.5194/acp-84027-2008, 2008.

10 Donateo, A., Contini, D., Belosi, F., Gambarano, A., Santachiara, G., Cesari, D., and Prodi, F.: Characterisation of $\mathrm{PM}_{2.5}$ concentrations and turbulent fluxes on a island of the Venice lagoon using high temporal resolution measurements, Meteorol. Z., 21, 4, 385-398, 2012.

Directive 2008/50/EC: Directive 2008/50/EC of the European parliament and of the council of 21 May 2008 on ambient air quality and cleaner air for Europe, Official Journal of the European Union, L 152/2, 11.6.2008.

El-Metwally, M. and Alfaro, S. C.: Correlation between meteorological conditions and aerosol characteristics at an East-Mediterranean coastal site, Atmos. Res., 132-133, 76-90, 2013.

Elsasser, M., Crippa, M., Orasche, J., DeCarlo, P. F., Oster, M., Pitz, M., Cyrys, J., Gustafson, T. L., Pettersson, J. B. C., Schnelle-Kreis, J., Prévôt, A. S. H., and Zimmermann, R.: Organic molecular markers and signature from wood combustion particles in winter ambient aerosols: aerosol mass spectrometer (AMS) and high time-resolved GC-MS measurements in Augsburg, Germany, Atmos. Chem. Phys., 12, 6113-6128, doi:10.5194/acp-12-6113-2012, 2012.

Emeis, S. and Schäfer, K.: Remote sensing methods to investigate boundary-layer structures relevant to air pollution in cities, Bound-Lay. Meteorol., 121, 377-385, 2006.

Emeis, S., Münkel, C., Vogt, S., Müller, W., and Schäfer, K.: Determination of mixing-layer height, Atmos. Environ., 38, 273-286, 2004.

Emeis, S., Jahn, C., Münkel, C., Münsterer, C., and Schäfer, K.: Multiple atmospheric layering and mixing-layer height in the Inn valley observed by remote sensing, Meteorol. Z., 16, 415424, 2007.

Emeis, S., Schäfer, K., and Münkel, C.: Surface-based remote sending of the mixing-layer height - a review, Meteorol. Z., 17, 621-630, 2008.
ACPD

14, 2235-2275, 2014

Meterological

conditions for air

pollution

K. Schäfer et al.

Title Page

Abstract

Introduction

Conclusions

References

Tables

Figures

14

$\rightarrow 1$

4

Back

Close

Full Screen / Esc

Printer-friendly Version

Interactive Discussion 
Emeis, S., Schäfer, K., and Münkel, C.: Observation of the structure of the urban boundary layer with different ceilometers and validation by RASS data, Meteorol. Z., 18, 149-154, 2009.

Emeis, S., Schäfer, K., Münkel, C., Friedl, R., and Suppan, P.: Evaluation of the interpretation of ceilometer data with RASS and radiosonde data, Bound-Lay. Meteorol., 143, 25-35, 2012.

5 Gu, J. W., Pitz, M., Schnelle-Kreis, J., Diemer, J., Reller, A., Zimmermann, R., Soentgen, J., Stoelzel, M., Wichmann, H. E., Peters, A., and Cyrys, J.: Source apportionment of ambient particles: comparison of positive matrix factorization analysis applied to particle size distribution and chemical composition data, Atmos. Environ., 45, 1849-1857, 2011.

Gu, J., Pitz, M., Breitner, S., Birmili, W., von Klot, S., Schneider, A., Soentgen, J., Reller, A., Peters, A., and Cyrys, J.: Selection of key ambient particulate variables for epidemiological studies - applying cluster and heatmap analyses as tools for data reduction, Sci. Total Environ., 435-436, 541-550, 2012.

Helmis, C. G., Sgouros, G., Tombrou, M., Schäfer, K., Münkel, C., Bossiolo, E., and Dandou, A.: A comparative study and evaluation of Mixing Height estimation based on SODAR-RASS, ceilometer data and model simulations, Bound.-Lay. Meteorol., 145, 507-526, 2012.

Jacobeit, J.: Stadtklimatologie von Augsburg unter besonderer Berücksichtigung der lufthygienischen Situation sowie des Lärms, Forschungsprojekt im Auftrag und mit Förderung der Stadt Augsburg, edited by: Fischer, K., Augsburger Geographische Hefte, 6, 171 pp., 1986.

Lanz, V. A., Alfarra, M. R., Baltensperger, U., Buchmann, B., Hueglin, C., and Prévôt, A. S. H.: 20 Source apportionment of submicron organic aerosols at an urban site by factor analytical modelling of aerosol mass spectra, Atmos. Chem. Phys., 7, 1503-1522, doi:10.5194/acp-71503-2007, 2007.

Liu, X., Gu, J., Li, Y., Cheng, Y., Qu, Y., Han, T., Wang, J., Tian, H., Chen, J., and Zhang, Y.: Increase of aerosol scattering by hygroscopic growth: observation, modeling, and implications on atmospheric visibility, Atmos. Res., 132, 91-101, 2013.

Malm, W. C. and Day, D. E.: Estimates of aerosol species scattering characteristics as a function of relative humidity, Atmos. Environ., 35, 2845-2860, 2001.

Münkel, C.: Mixing height determination with lidar ceilometers - results from Helsinki Testbed, Meteorol. Z., 16, 451-459, 2007.

30 Münkel, C., Schäfer, K., and Emeis, S.: Confidence levels and error bars for continuous detection of mixing layer heights by ceilometer, in: Extended Abstracts of Presentations from the 16th International Symposium for the Advancement of Boundary-Layer Remote Sensing, 5-8 June 2012, Boulder, CO USA, 98-101, 2012.
ACPD

14, 2235-2275, 2014

Meterological

conditions for air

pollution

K. Schäfer et al.

Title Page 
Paatero, P.: Least squares formulation of robust non-negative factor analysis, Chemometr. Intell. Lab., 37, 23-35, 1997.

Paatero, P. and Tappert, U.: Positive matrix factorization: a non-negative factor model with optimal utilization of error estimated of data values, Environmetrics, 5, 111-126, 1994.

5 Pitz, M., Birmili, W., Schmid, O., Peters, A., Wichmann, H. E., and Cyrys, J.: Quality control and quality assurance for particle size distribution measurements at an urban monitoring station in Augsburg, Germany, J. Environ. Monitor, 10, 1017-1024, 2008.

Rückerl, R., Schneider, A., Breitner, S., Cyrys, J., and Peters, A.: Health effects of particulate air pollution - a review of epidemiological evidence, Inhal. Toxicol., 23, 555-592, 2011.

10 Schäfer, K, Emeis, S., Hoffmann, H., and Jahn, C.: Influence of mixing layer height upon air pollution in urban and sub-urban areas, Meteorol. Z., 15, 647-658, 2006.

Schäfer, K., Emeis, S., Schrader, S., Török, S., Alföldy, A., Osan, J., Pitz, M., Münkel, C., Cyrys, J., Peters, A., Sarigiannis, D., and Suppan, P.: A measurement based analysis of the spatial distribution, temporal variation and chemical composition of particulate matter in Munich and Augsburg, Meteorol. Z., 21, 47-57, 2011.

Schäfer, K., Pitz, M., Höss, M., Friedl, R., Emeis, S., Münkel, C., Cyrys, J., Schrader, S., Hoffmann, M., Jahn, C., Jacobeit, J., Peters, A., Soentgen, J., and Suppan, P.: Investigation of meteorological influences and mixing-layer height upon ultrafine particle size distribution in the urban area of Augsburg, in: Book of Abstracts, 8th International Conference on Air Quality, Science and Application, Athens, Greece, 19-23 March 2012, University of Hertfordshire, 121, ISBN: 978-1-907396-80-9, 2012.

Stat. Jahrbuch: Statistisches Jahrbuch der Stadt Augsburg, online available at: http://www.augsburg.de/fileadmin/user_upload/buergerservice_rathaus/rathaus/statisiken_ und_geodaten/statistiken/jahrbuch/jahrbuch_2012.pdf (last access: 23 January 2014), 2013.

Sueper, D.: ToF-AMS High Resolution Analysis Software - Pika, online available at: http: //cires.colorado.edu/jimenez-group/ToFAMSResources/ToFSoftware/Pikalnfo/ (last access: 23 January 2014), 2010.

Tai, A. P. K., Mickley, L. J., and Jacob, D. J.: Correlations between fine particulate matter $\left(\mathrm{PM}_{2.5}\right)$ 30 and meteorological variables in the United States: implications for the sensitivity of $\mathrm{PM}_{2.5}$ to climate change, Atmos. Environ., 44, 3976-3984, 2010.

Tandon, A., Yadav, S., and Attri, A. K.: Coupling between meteorological factors and ambient aerosol load, Atmos. Environ., 44, 1237-1243, 2010.

\section{Meterological \\ conditions for air pollution}

K. Schäfer et al.

\section{Title Page}

\section{Abstract}

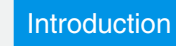

Conclusions

References

Tables

Figures

14

$\rightarrow 1$

4

Back

Close

Full Screen / Esc

Printer-friendly Version

Interactive Discussion 
Ulbrich, I. M., Canagaratna, M. R., Zhang, Q., Worsnop, D. R., and Jimenez, J. L.: Interpretation of organic components from Positive Matrix Factorization of aerosol mass spectrometric data, Atmos. Chem. Phys., 9, 2891-2918, doi:10.5194/acp-9-2891-2009, 2009.

Wen, C.-C., and Yeh, H.-H.: Comparative influences of airborne pollutants and meteorological 5 parameters on atmospheric visibility and turbidity, Atmos. Res., 96, 496-509, 2010.

Wu, S., Deng, F., Wang, X., Wei, H., Shima, M., Huang, J., Lv, H., Hao, Y., Zheng, C., Qin, Y., Lu, X., and Guo, X.: Association of Lung Function in A Panel of Young Healthy Adults with Various Chemical Components of Ambient Fine Particulate Air Pollution in Beijing, China, Atmos. Environ., 77, 873-884, 2013.

10 Zhang, Q. H., Zhang, J. P., and Xue, H. W.: The challenge of improving visibility in Beijing, Atmos. Chem. Phys., 10, 7821-7827, doi:10.5194/acp-10-7821-2010, 2010.

Zhao, P., Zhang, X., Xu, X., and Zhao, X.: Long-term visibility trends and characteristics in the region of Beijing, Tianjin, and Hebei, China, Atmos. Res., 101, 711-718, 2011.

Yue, D., Hu, M., Wu, Z., Wang, Z., Guo, S., Wehner, B., Nowak, A., Achtert, P., Wiedensohler, A., Jung, J., Kim, Y. J., and Liu, S.: Characteristics of aerosol size distributions and new particle formation in the summer in Beijing, J. Geophys. Res., 114, D00G12, doi:10.1029/2008JD010894, 2009.

\section{ACPD}

$14,2235-2275,2014$

\section{Meterological \\ conditions for air \\ pollution}

K. Schäfer et al.

\section{Title Page}




\section{ACPD}

14, 2235-2275, 2014

\section{Meterological \\ conditions for air \\ pollution}

Table 1. Correlation coefficients $R^{2}$ of hourly-mean values of $\mathrm{NO}$ and $\mathrm{NO}_{\mathrm{x}}$ concentrations measured at the station Bourgesplatz with the measured concentrations at the stations LfU and urban edge background site (AVA), $\mathrm{O}_{3}$ and $\mathrm{CO}$ concentrations measured at the station LfU with the measured concentrations at the urban edge background site (AVA) as well as $\mathrm{PM}_{2.5}$ and $\mathrm{PM}_{10}$ concentrations measured at the station LfU with the urban background site (HSA). No correlations are given if no data are available.

\begin{tabular}{lrrrrrr}
\hline Site & $\mathrm{NO}$ & $\mathrm{NO}_{\mathrm{x}}$ & $\mathrm{O}_{3}$ & $\mathrm{CO}$ & $\mathrm{PM}_{2.5}$ & $\mathrm{PM}_{10}$ \\
\hline AVA & 0.45 & 0.60 & 0.88 & 0.78 & & \\
HSA & & & & & 0.93 & 0.86 \\
$\begin{array}{l}\text { Bourgesplatz } \\
\text { LfU }\end{array}$ & 1 & 1 & & & & \\
& 0.54 & 0.65 & 1 & 1 & 1 & 1 \\
\hline
\end{tabular}

K. Schäfer et al.

Title Page

Abstract

Conclusions

Tables

14

4

Back
Introduction

References

Figures

$>1$

$>$

Close

\section{Full Screen / Esc}

Printer-friendly Version

Interactive Discussion 


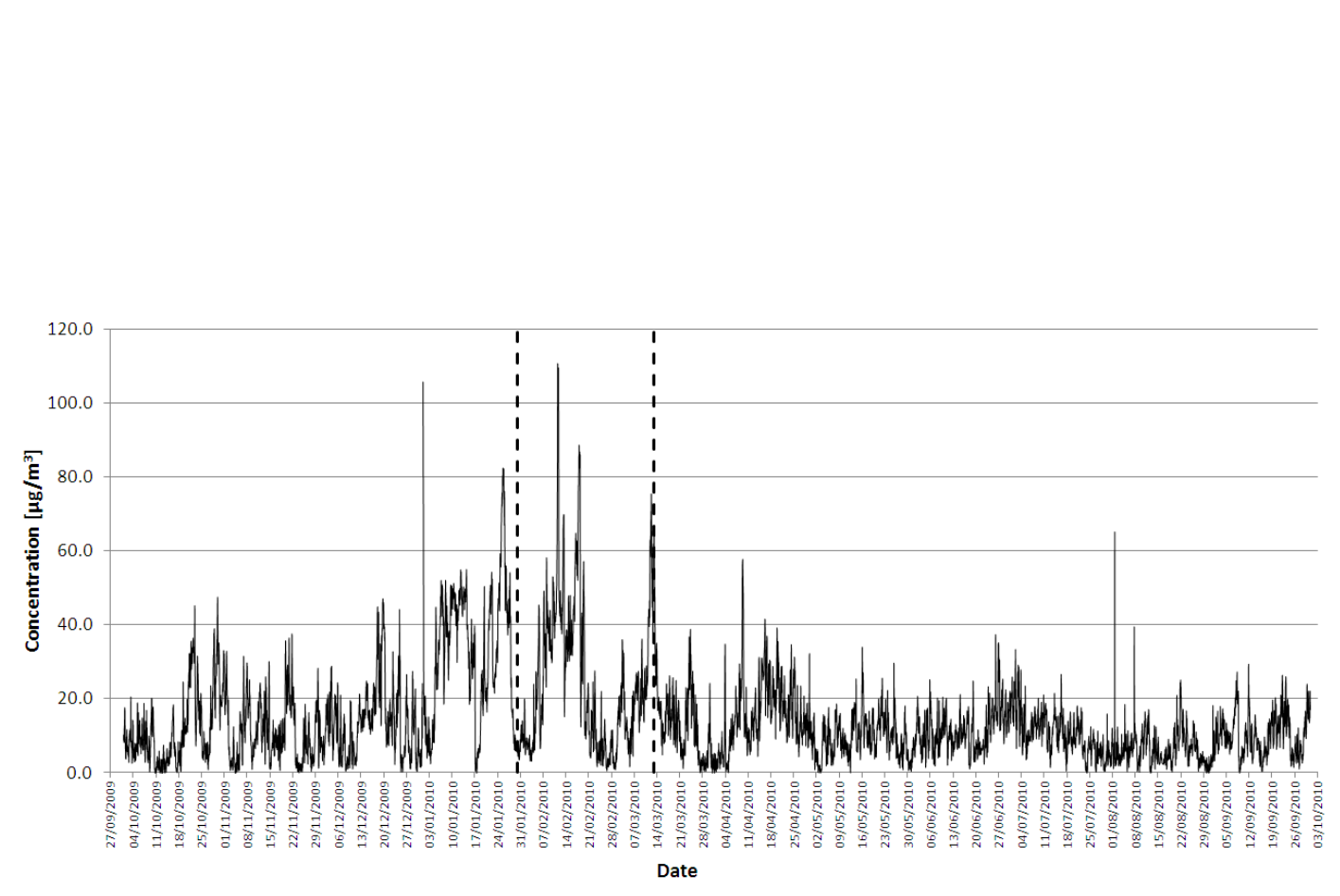

Fig. 1. Time series of hourly-mean values of $\mathrm{PM}_{2.5}$ concentration measurements at the urban background site HSA from 01 October 2009 to 30 September 2010. The measurement period from 31 January, 00:00 CET to 12 March 2010, 24:00 CET is indicated by dashed lines.

\section{ACPD}

14, 2235-2275, 2014

\section{Meterological} conditions for air pollution

K. Schäfer et al.

\section{Title Page}

Abstract

Introduction

Conclusions

References

Tables

Figures

$1<$

DI

4

Back

Close

Full Screen / Esc

Printer-friendly Version

Interactive Discussion 


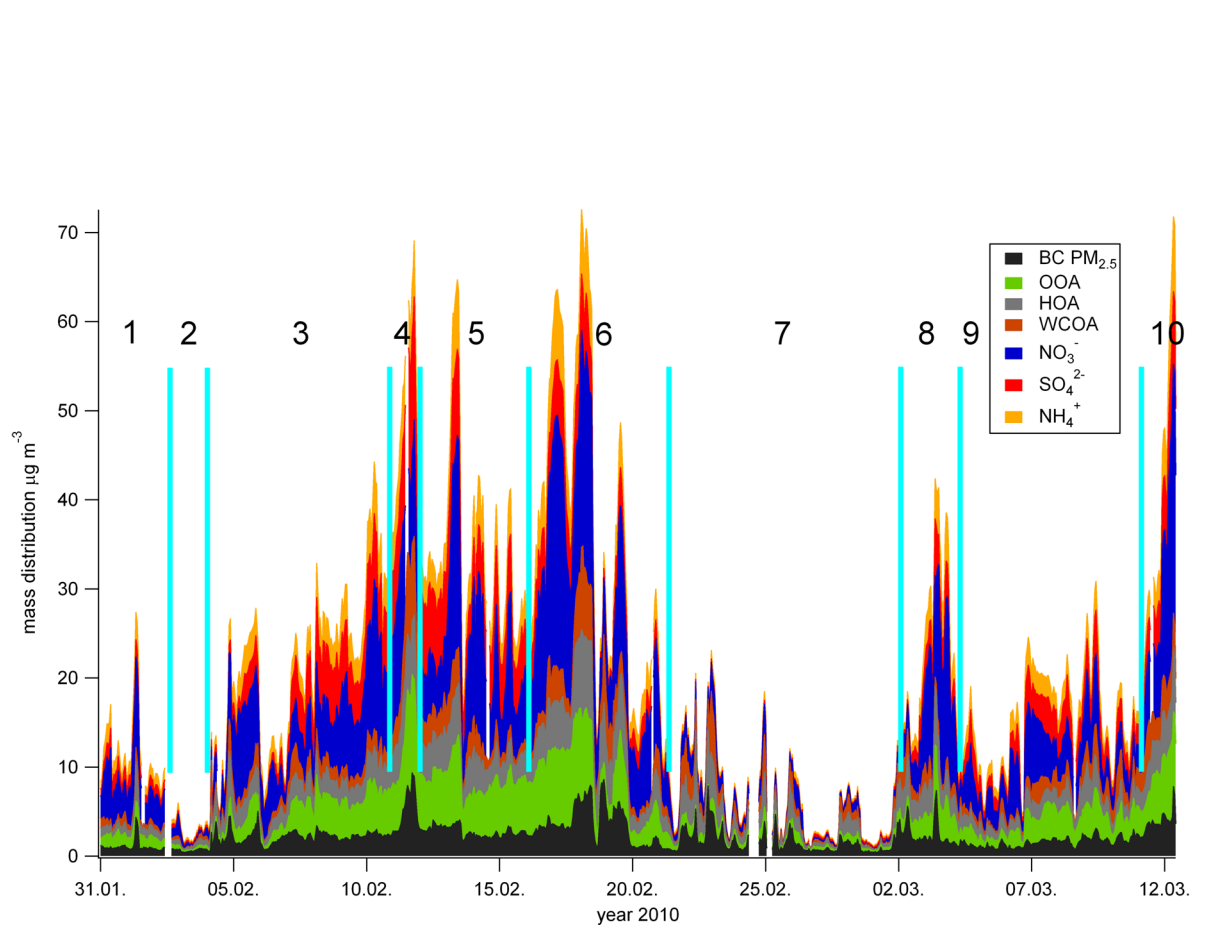

Fig. 2. 10 temporal phases of $P M_{1}$ fractions and $B C$ from $P M_{2.5}$ on the basis of hourly-mean values measured at the urban background site HSA (data source from Elsasser et al., 2012): BC - black carbon, OOA - oxygenated organic aerosol, $\mathrm{HOA}$ - hydrocarbon-like organic aerosol, WCOA - wood combustion organic aerosol, $\mathrm{NO}_{3}^{-}-$nitrate, $\mathrm{SO}_{4}^{2-}-$ sulphate, and $\mathrm{NH}_{4}^{+}-$ammonium (see text and Table S1 in the supplements). The border of the phases are coloured in light blue.

\section{ACPD}

14, 2235-2275, 2014

\section{Meterological conditions for air pollution}

K. Schäfer et al.

\section{Title Page}

Abstract

Introduction

Conclusions

References

Tables

Figures

14

$>$

4

Back

Close

\section{Full Screen / Esc}

Printer-friendly Version

Interactive Discussion 


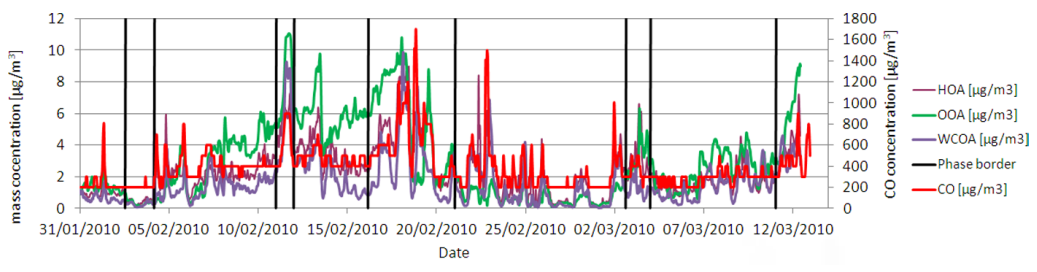

\section{ACPD}

14, 2235-2275, 2014

\section{Meterological conditions for air pollution}

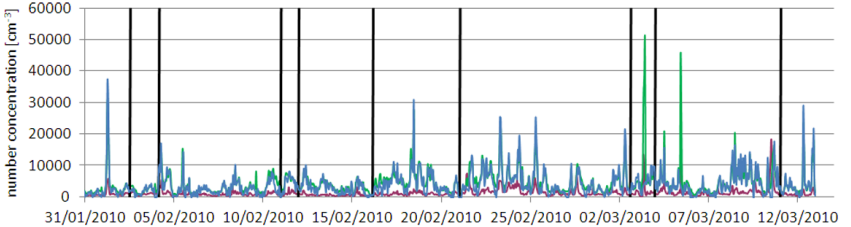

K. Schäfer et al.

$31 / 01 / 2010$ 05/02/2010 10/02/2 Date

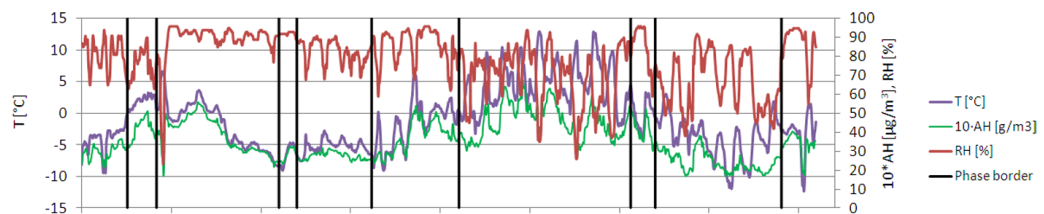

Title Page

Abstract

Introduction

$\begin{array}{llllllllll}-15 & 02 / 03 / 2010 & 07 / 03 / 2010 & 12 / 03 / 2010\end{array}$

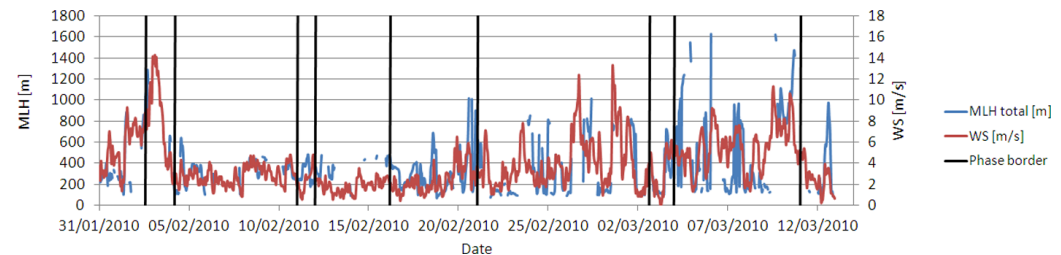

Conclusions

References

Tables

Figures

$1<$

$>1$

Back

$>$

Close

\section{Full Screen / Esc}

Fig. 3. Temporal variation of OOA (oxygenated organic aerosol), HOA (hydrocarbon-like organic aerosol), WCOA (wood combustion organic aerosol) and CO concentrations (above), NC3-10, NC10-30 and the fresh aerosol factor (second from above) together with the meteorological parameters $T$ (temperature), $\mathrm{RH}$ (relative humidity) and $\mathrm{AH}$ (absolute humidity) (third from above) and WS (wind speed) and mixing layer height (MLH) (below). The borders of the 10 phases are drawn too.

Printer-friendly Version

Interactive Discussion 


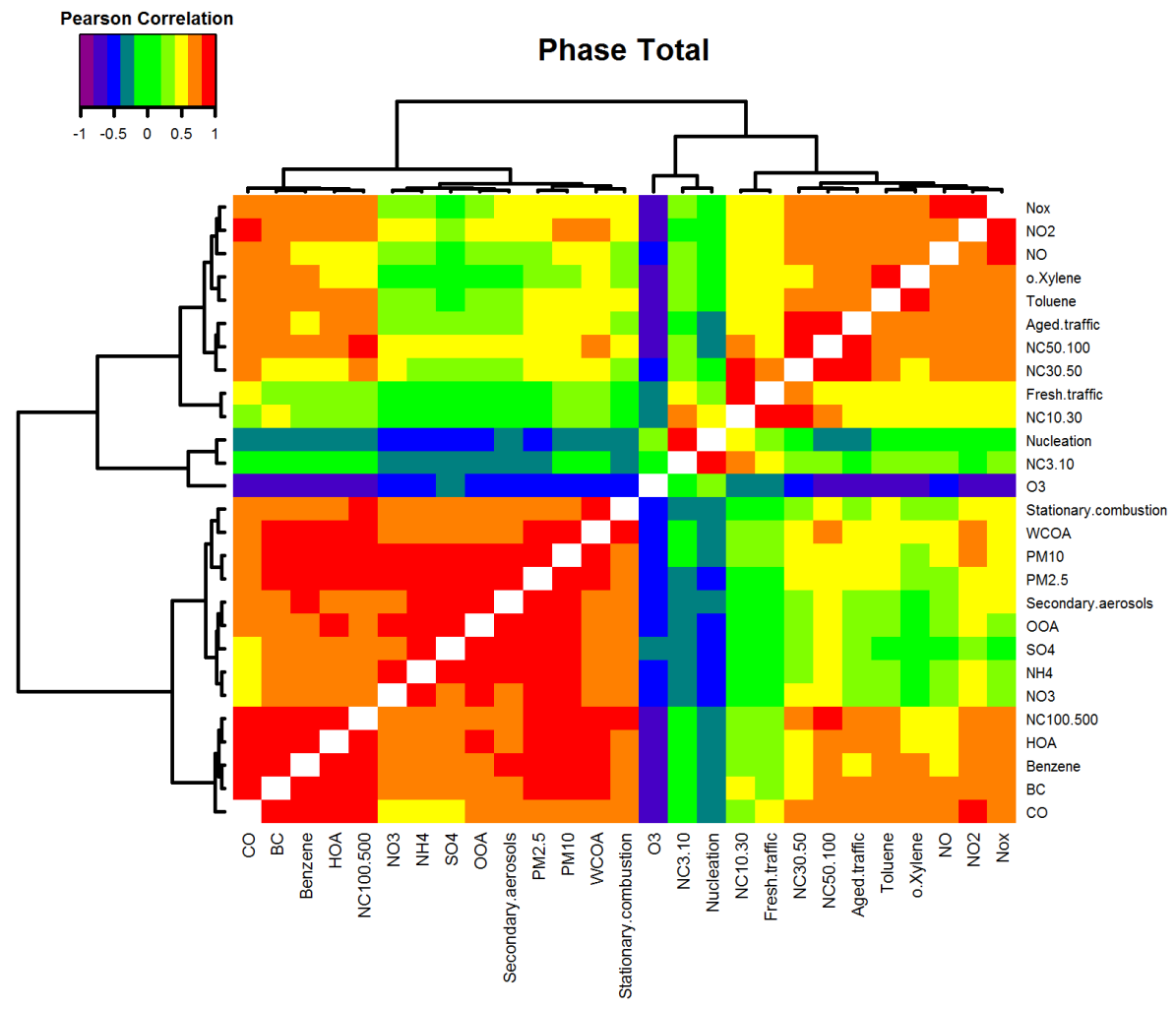

\section{ACPD}

14, 2235-2275, 2014

\section{Meterological conditions for air pollution}

K. Schäfer et al.

Title Page

4

\section{Back}

$>$

\section{Full Screen / Esc}

Printer-friendly Version

Interactive Discussion 
ACPD

14, 2235-2275, 2014

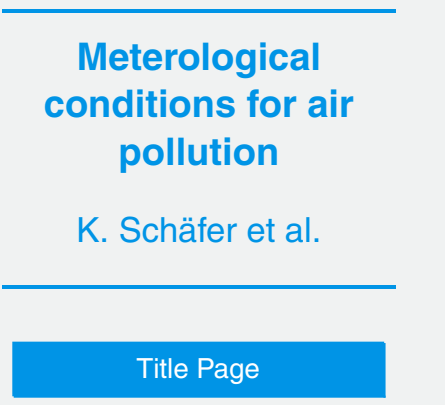

Abstract

Introduction

Conclusions

References

Tables

Figures

14

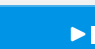

4

Back

Close

Full Screen / Esc

Printer-friendly Version

Interactive Discussion 

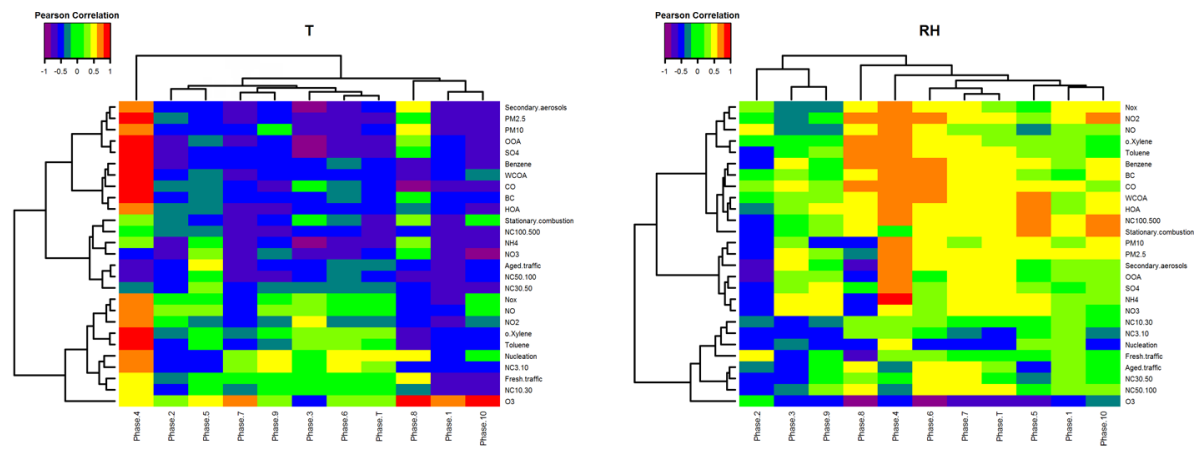

\section{ACPD}

14, 2235-2275, 2014

\section{Meterological} conditions for air pollution

K. Schäfer et al.
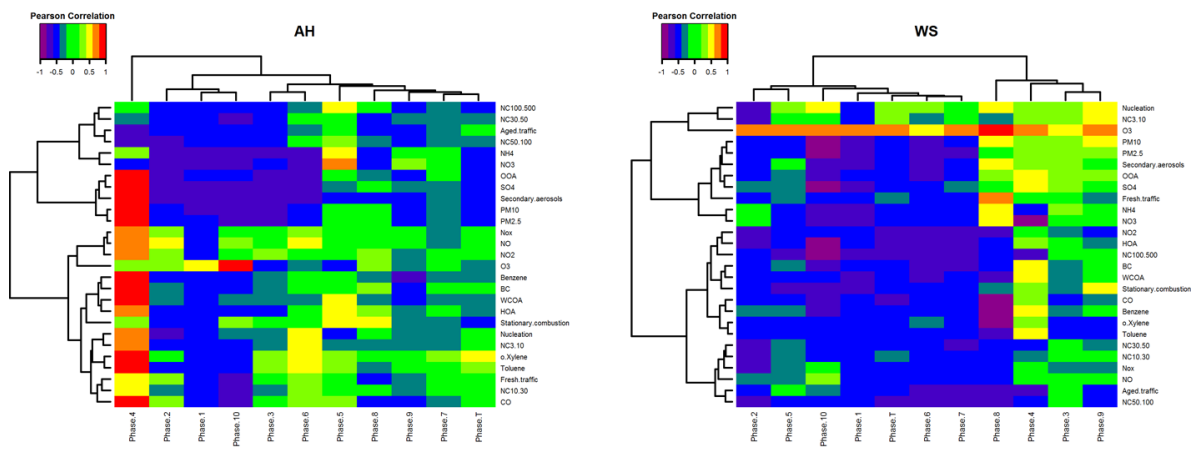

Title Page

Abstract

Introduction

Conclusions

References

Tables

Figures

14

$>1$

4

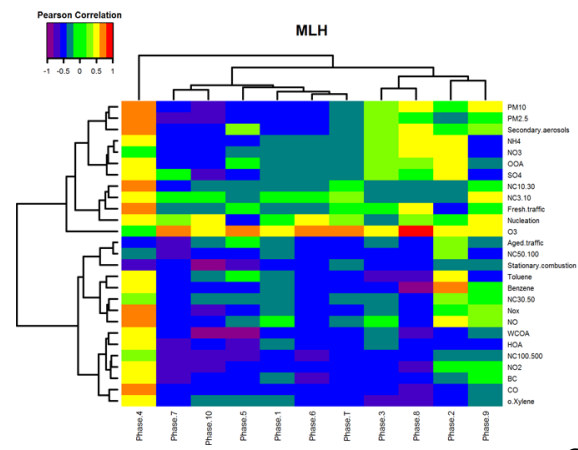

$\checkmark$

Close

Full Screen / Esc

Printer-friendly Version

Interactive Discussion

(c) (1) 
Fig. 5. Heatmap with Pearson intercorrelations between pollutants and meteorological parameters ( $T$ (temperature), $\mathrm{RH}$ (relative humidity), AH (absolute humidity), WS (wind speed), MLH (mixing layer height)) during the total measurement period (each temporal phase and total period) showing different clusters including the dendrogram on the columns and rows. The correlations are coloured according to the scale on the top-left corner.

\section{ACPD}

14, 2235-2275, 2014

\section{Meterological \\ conditions for air pollution}

K. Schäfer et al.

\section{Title Page}

\section{Full Screen / Esc}

Printer-friendly Version

Interactive Discussion 

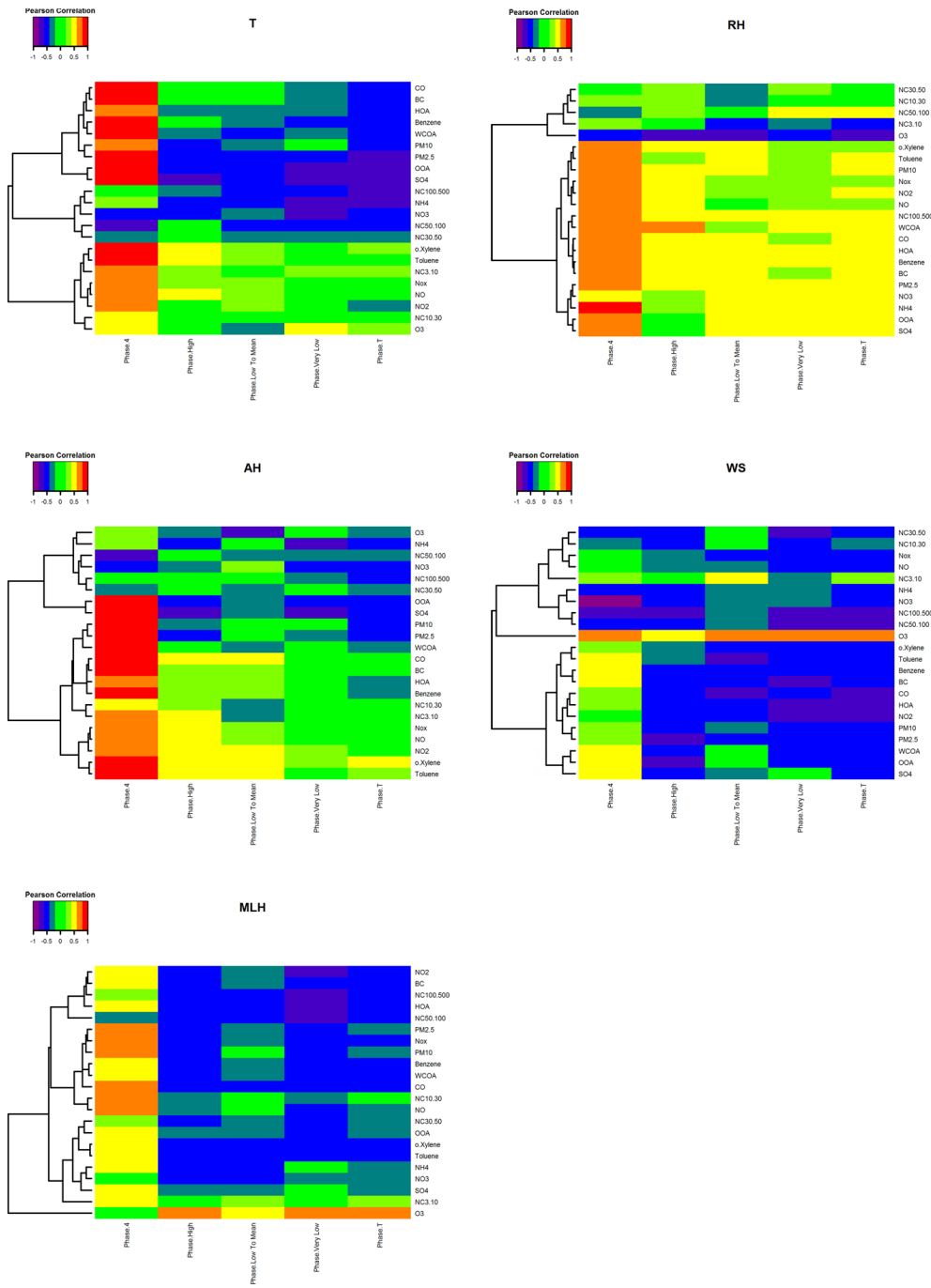

\section{ACPD}

14, 2235-2275, 2014

Meterological conditions for air pollution

K. Schäfer et al.

Title Page

Abstract

Introduction

Conclusions

References

Tables

Figures

14

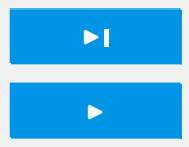

Back

Close

Full Screen / Esc

Printer-friendly Version

Interactive Discussion

(c) (1) 
Fig. 6. Heatmap with Pearson intercorrelations between pollutants and meteorological parameters ( $T$ (temperature), $\mathrm{RH}$ (relative humidity), AH (absolute humidity), WS (wind speed), MLH (mixing layer height)) during the measurement period for three groups (phases Very Low, Low To Mean and High concentrations), phase 4 and total period (phase Total) including the dendrogram on the rows. The correlations are coloured according to the scale on the top-left corner.

\section{ACPD}

14, 2235-2275, 2014

\section{Meterological \\ conditions for air \\ pollution}

K. Schäfer et al.

\section{Title Page}

\section{Full Screen / Esc}

Printer-friendly Version

Interactive Discussion 


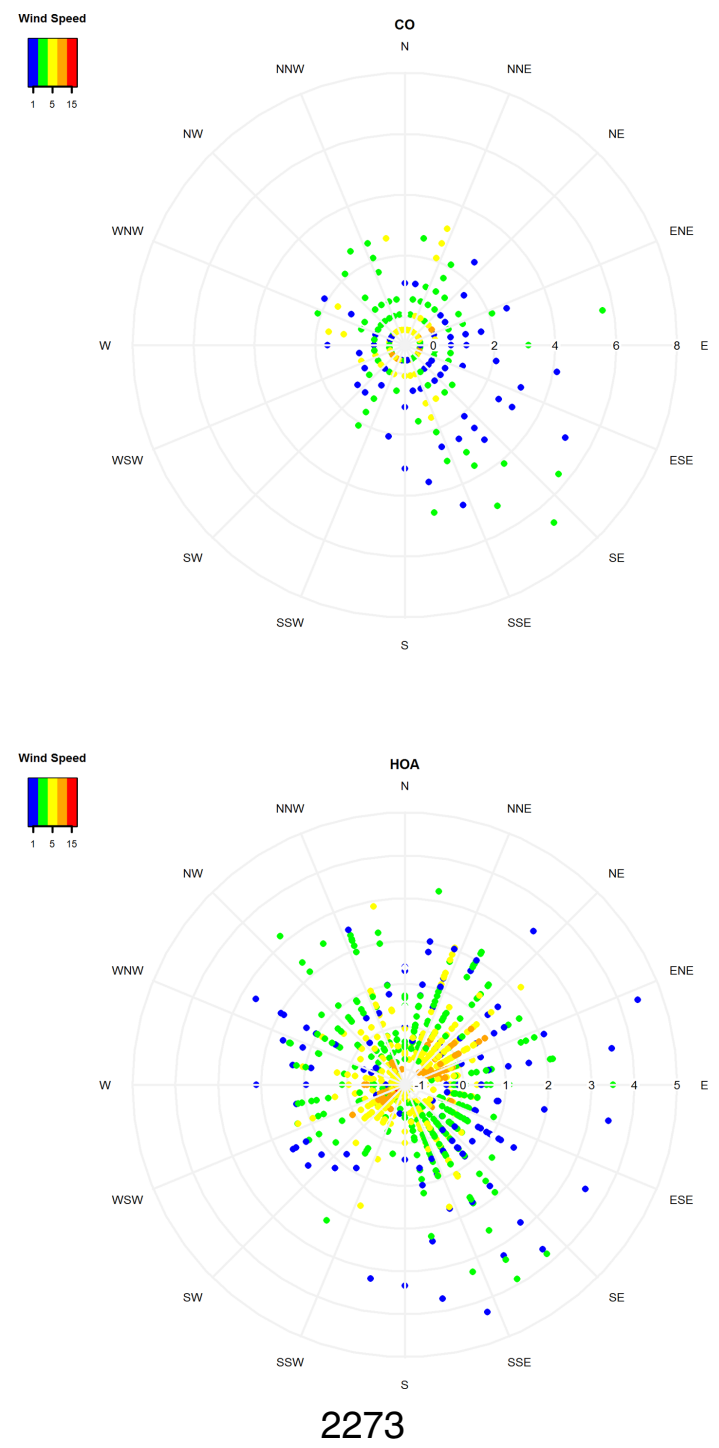

\section{ACPD}

14, 2235-2275, 2014

\section{Meterological conditions for air} pollution

K. Schäfer et al.

Title Page

\section{Abstract \\ Introduction \\ Conclusions \\ References}

Tables

Figures

14

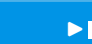

4

Back

$>$

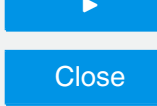

Full Screen / Esc

Printer-friendly Version

Interactive Discussion

(c) (1) 
Fig. 7. Wind direction, wind speed (in different colours, units in $\mathrm{m} \mathrm{s}^{-1}$ ) and concentration (in different distance to the middle, scale on the horizontal line in $\mathrm{mg} \mathrm{m}^{-3}$ ) plots in polar coordinates for $\mathrm{CO}$ and $\mathrm{HOA}$ - hydrocarbon-like organic aerosol. Calm wind situations are in blue. The correlations are coloured according to the scale on the top-left corner.

\section{ACPD}

14, 2235-2275, 2014

\section{Meterological}

conditions for air

pollution

K. Schäfer et al.

\section{Title Page}

\section{Full Screen / Esc}

Printer-friendly Version

Interactive Discussion 


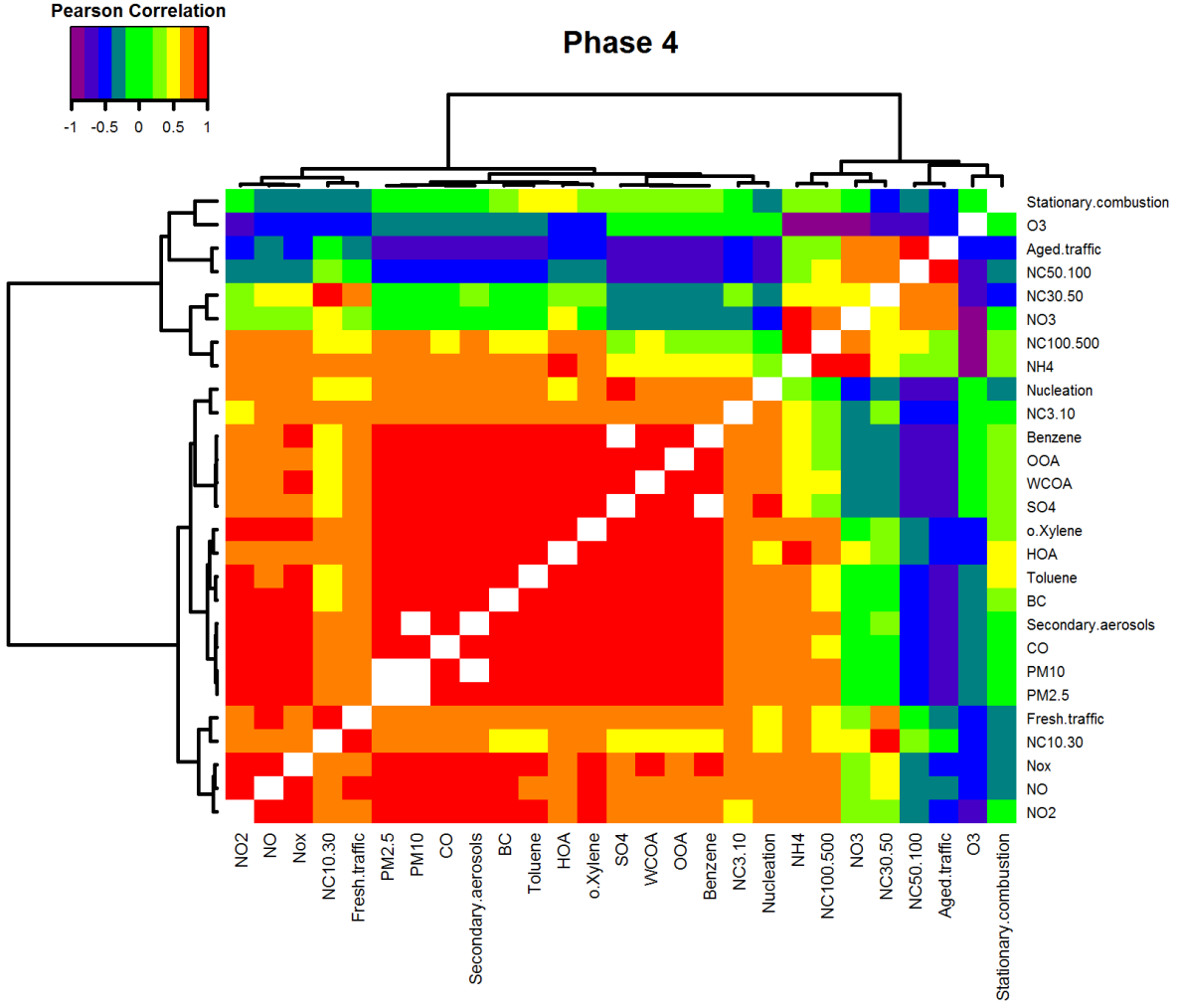

Fig. 8. Heatmap with Pearson intercorrelations between all pollutants during phase 4 showing different clusters including the dendrogram on the rows and columns. The correlations are coloured according to the scale on the top-left corner.

\section{ACPD}

14, 2235-2275, 2014

\section{Meterological conditions for air pollution}

K. Schäfer et al.

Title Page

Abstract

Introduction

Conclusions

References

Tables

Figures

$1<$

$>1$

4

Back

Close 